\title{
Assessing manure and inorganic nitrogen fertilization impacts on soil health, crop productivity, and crop quality in a continuous maize agroecosystem
}

G.L. Miner, J.A. Delgado, J.A. Ippolito, C.E. Stewart, D.K. Manter, S.J. Del Grosso, B.A. Floyd, and R.E. D’Adamo

\begin{abstract}
Sustainable agricultural production requires an inclusive framework that concurrently considers the impacts of production methods on soil health, crop productivity, and crop nutritional quality. However, few studies have directly examined the potential associations among management impacts on soil health $(\mathrm{SH})$, crop productivity, and crop quality. We evaluated these linkages in a continuous maize experiment with treatments varying in nitrogen $(\mathrm{N})$ fertilizer amount and type (zero input control, inorganic $\mathrm{N}$, and manure-based $\mathrm{N}$ treatment). We evaluated select $\mathrm{SH}$ indicators after six cropping years, and computed physical, chemical, biological, nutrient, and overall SH indices using the Soil Management Assessment Framework (SMAF). Crop yields, mineral nutrient concentrations (denoted with brackets), and nutrient uptake were analyzed in years six and seven. Manure application increased biological SH indicators compared to the control and inorganic $\mathrm{N}$ treatments and also increased available potassium $(\mathrm{K})$, zinc $(\mathrm{Zn})$, copper $(\mathrm{Cu})$, and phosphorus $(\mathrm{P})$. Overall $\mathrm{SH}$ indices were higher in the inorganic $\mathrm{N}$ and manure treatments than in the control but did not differ between the two $\mathrm{N}$ sources, despite the large exogenous sources of $\mathrm{C}, \mathrm{N}$, and nutrients applied via manure. The SMAF tool only directly considers $\mathrm{P}$ and $\mathrm{K}$ in terms of soil nutrients-other nutrient benefits of manure application (i.e., increases in total soil $\mathrm{N}$, available $\mathrm{Cu}$ and $\mathrm{Zn}$ ) were not accounted for, suggesting that the SMAF nutrient $\mathrm{SH}$ index should be modified to account for the impacts of management practices on nutrient availability. Crop yields were higher in treatments with higher overall $\mathrm{SH}$, supporting the linkages between $\mathrm{SH}$ and crop productivity. Despite widely differing nutrient inputs and soil fertility levels, we found no yield differences between the two $\mathrm{N}$ sources. However, there were notable treatment impacts on crop quality. Grain $[\mathrm{N}]$ was $40 \%$ greater in the urea and manure treatments than in the control. Grain $[\mathrm{P}],[\mathrm{K}]$, and $[\mathrm{Mg}]$, important elements in livestock nutrition, were $10 \%$ to $28 \%$ greater in the manure treatment than in the urea treatment. In addition, although a yield dilution of grain $[\mathrm{Zn}]$ occurred in the urea treatment, the dilution effect was mitigated in the manure treatment, likely due to increases in available Zn. Overarchingly, our results suggest that management practices that maintain or improve $\mathrm{SH}$ and nutrient availability also improve maize productivity and nutritional quality, which could have cascading positive impacts on animal and human nutrition.
\end{abstract}

Key words: crop quality—maize — manure — nitrogen—productivity—soil health

Agriculture is, in the most basic sense, the provider of the essential nutrition for life. While extensive agricultural investment in the latter half of the twentieth century

Received June 11, 2019; Revised September 30, 2019; Accepted November 5, 2019; Published online June 11, 2020. maintaining and improving soil health $(\mathrm{SH})$, and sustaining or improving crop nutritional quality for human and animal health (Graham et al. 2001).

Soil health, also referred to as soil quality, is defined as "the continued capacity of soil to function as a vital living ecosystem that sustains plants, animals, and humans" (USDA NRCS 2019). Decades of research have focused on developing indicators and frameworks to evaluate $\mathrm{SH}$ (Bünemann et al. 2018; Doran and Parkin 1994; MoebiusClune et al. 2016). Tools such as the Soil Management Assessment Framework (SMAF) integrate individual $\mathrm{SH}$ indicators into physical, chemical, biological, and nutrient index scores, which can be combined to produce an overall $\mathrm{SH}$ index (Andrews et al. 2004).

Numerous researchers have suggested that improvements in $\mathrm{SH}$ also lead to increases in crop productivity and nutritional quality (Pepper 2013; Wall et al. 2015; Warkentin 1995). Although improvements in $\mathrm{SH}$ can potentially promote crop yields in some systems via increased nutrient cycling and water capture, these linkages are only beginning to be quantitatively explored (Roper et al. 2017). However, increases in crop yields do not necessarily lead to increases in nutritional quality. The mineral nutritional component of crop quality (e.g., oil, protein, starch, or mineral macro- and micronutrients) is an enduring point of concern and interest, as deficiencies in nutrients, such as iron $(\mathrm{Fe})$ and zinc $(\mathrm{Zn})$, impact an estimated third to half of the global population (Miller and Welch 2013). Sufficient crop nutrient concentrations (denoted with brackets) are also necessary for meeting the nutritional needs of livestock (Gupta et al. 2008).

Grace L. Miner is a postdoctoral plant scientist in the Department of Soil and Crop Sciences, Colorado State University, Fort Collins, Colorado, and a visiting scientist with the USDA Agricultural Research Service Soil Management and Sugarbeet Research Unit, Fort Collins, Colorado. Jorge A. Delgado, Catherine E. Stewart, Daniel K. Manter, and Stephen J. Del Grosso are research soil scientists and Robert E. D'Adamo and Bradley A. Floyd are physical science technicians at the USDA Agricultural Research Service Soil Management and Sugarbeet Research Unit, Fort Collins, Colorado. James A. Ippolito is an associate professor of environmental soil quality in the Department of Soil and Crop Sciences, Colorado State University, Fort Collins, Colorado. 
Maize (Zea mays L.) has been called a "paramount staple crop" in global nutrition, serving as a staple in the diet of over 200 million people, and provides an important entry point for nutrients into the global food chain (Nuss and Tanumihardjo 2010). Maintaining or increasing mineral nutrients in staple crops such as maize is a critical component of combating nutrient deficiencies, yet the interrelationships among management practices, $\mathrm{SH}$, crop productivity, and crop quality are poorly understood.

Soil organic carbon (SOC) is widely considered the most important baseline measurement of SH due to its influence on multiple biological, chemical, and physical soil properties (Doran and Parkin 1994). Hence, when looking for linkages between $\mathrm{SH}$, crop productivity, and crop quality, a good model system for study is one with treatments receiving exogenous sources of organic C (e.g., manure, other organic amendments) versus systems receiving only inorganic fertilizer or no additional inputs. Manure additions result in large direct $\mathrm{C}$ inputs that can increase SOC more effectively than mineral fertilizers (Maillard and Angers 2014; van der Bom et al. 2019). Increases in $\mathrm{C}$ via manure application can increase soil microbial biomass and activity (Kallenbach and Grandy 2011), with subsequent positive impacts on soil physical properties such as macro aggregation (Chaney and Swift 1984; Mikha and Rice 2004). In addition, manure contains other macro- and micronutrients, and repeated years of application effectively builds soil nutrient pools (Eghball and Power 1999b; Eghball et al. 2002).

However, there are tradeoffs between inorganic and manure-based $\mathrm{N}$ fertilization (Ribaudo et al. 2011). Notably, the nitrogen $(\mathrm{N})$ in manure must be mineralized before it is plant available, making it difficult to ensure that $\mathrm{N}$ is available at critical crop growth stages (Eghball et al. 2002). Manure application rates that are sufficient to meet crop $\mathrm{N}$ needs can result in overapplication of phosphorus $(\mathrm{P})$, as the crop $\mathrm{N}: \mathrm{P}$ uptake ratio is higher than the ratio in manure (Schröder 2005). Elevated soil P concentrations are of environmental concern if $\mathrm{P}$ is moved via erosion into water bodies, where it can cause eutrophication (Hansen et al. 2002).

Real challenges and potential tradeoffs exist in production agriculture, underscoring the importance of concurrently assessing management impacts on $\mathrm{SH}$, crop produc- tivity, and crop quality. Our study objectives were (1) to evaluate changes in $\mathrm{SH}$ indicators and composite indices in response to soil amendments (zero $\mathrm{N}$ control, inorganic $\mathrm{N}$ treatment, and manure-based $\mathrm{N}$ treatment), and (2) to assess whether shifts in SH resulted in concurrent impacts on crop productivity and crop quality.

\section{Materials and Methods}

The study was located on a Fort Collins clay loam soil (fine-loamy, mixed, mesic Aridic Haplustalfs; $1 \%$ to 2\% slope) at the Agricultural Research Development and Education Center near Fort Collins, Colorado. The study was initiated in 2012, with experimental plots laid out as a randomized complete block design with four replicates and multiple $\mathrm{N}$ source treatments (Halvorson et al. 2016). This experiment simulated a modified continuous corn production system, wherein stover was cut and baled after grain harvest, leaving only 5 to $7 \mathrm{~cm}$ stalk stubs in the field. Baseline soil properties in the 0 to $7.5 \mathrm{~cm}$ soil depth for the plot area were the following: $\mathrm{pH}$ at 8.0 (1:1); SOC at $11.9 \mathrm{~g} \mathrm{~kg}^{-1}$; total soil $\mathrm{N}$ at 1.5 $\mathrm{g} \mathrm{N} \mathrm{kg}^{-1}$; electrical conductivity (EC) at 0.58 $\mathrm{dS} \mathrm{m} \mathrm{m}^{-1}$; bulk density at $1.34 \mathrm{~g} \mathrm{~cm}^{-3}$; sand at $409 \mathrm{~g} \mathrm{~kg}^{-1}$; and clay at $337 \mathrm{~g} \mathrm{~kg}^{-1}$. For the current study, we examine three $\mathrm{N}$ source treatments - a control treatment with no N applied, an inorganic $\mathrm{N}$ treatment $(179 \mathrm{~kg} \mathrm{~N}$ $\mathrm{ha}^{-1}$ ), and a dairy manure treatment (target seasonal $\mathrm{N}$ availability of $179 \mathrm{~kg} \mathrm{~N} \mathrm{ha}{ }^{-1}$ ).

Each spring, manure was sourced from a local dairy and stockpiled in $2 \times 20 \mathrm{~m}$ piles for $\sim 30$ days prior to application. The manure was mixed one to two times in that period to promote homogenization. One week prior to application, samples were taken to determine $\mathrm{N}$ content to calculate application rates. Due to the short mixing time and low air temperatures, we assumed that $40 \%$ of total $\mathrm{N}$ applied would be available during the first growing season, similar to estimates for fresh manure (Eghball and Power 1999b). The water content of the stockpiled manure was measured $\sim 24$ hours prior to application. Manure was hand applied to plots between March 15 and April 15. Four subsamples of the manure applied to each plot were also collected the day of application and composited. Samples were dried at $60^{\circ} \mathrm{C}$ until a constant weight, ground to pass a $150 \mathrm{um}$ screen, and analyzed via combustion for total $\mathrm{N}$ and $\mathrm{C}$ (Elementar Americas Inc.,
Mt. Laurel, New Jersey). Samples from each plot were also sent to the Soil, Water, and Plant Testing Laboratory at Colorado State University for $\mathrm{pH}$, total $\mathrm{P}$, total potassium $(\mathrm{K})$, extractable bases, total and available micronutrients, and soluble salt determination. Manure application rates, estimates of annual nutrient additions, and manure characteristics are presented in tables 1 and 2 .

Manure was incorporated via rototiller the same day as application to a depth of $\sim 15 \mathrm{~cm}$ (simulating tillage) to reduce $\mathrm{N}$ losses (Leikam and Lamond 2003). All plots in the study, including the urea and control treatments, were tilled the same day. Maize was planted into the tilled seedbed each year. In 2017, the hybrid was Channel 192-09VT3PRIB. This variety was unavailable for the 2018 growing season, so a variety was chosen that closely matched the 2017 hybrid (Channel 193-53STXRIB). Urea was broadcast at emergence each year at a rate of $179 \mathrm{~kg} \mathrm{~N} \mathrm{ha}^{-1}$, with irrigation applied within two days. Triple superphosphate (0-46-0) was applied via surface broadcast to the urea and control treatments at a rate of $56 \mathrm{~kg} \mathrm{P}$ $\mathrm{ha}^{-1}$ in 2013, 2015, and 2018 to avoid P deficiencies. Soil moisture was monitored with Watermark sensors (Spectrum Technologies Inc.), and water was applied as needed via a linear-move irrigation system. Growing season precipitation (April to October) totaled $298 \mathrm{~mm}$ in 2017 versus $192 \mathrm{~mm}$ in 2018 . Total growing season water (precipitation + irrigation) totaled $673 \mathrm{~mm}$ in 2017 and 719 $\mathrm{mm}$ in 2018.

Soil Analyses. Soil samples were collected in May of 2018 after manure and urea applications. Two soil cores were collected in each plot (0 to $30 \mathrm{~cm})$; separated into increments of 0 to $7.5,7.5$ to 15 , and 15 to 30 $\mathrm{cm}$; and composited. Samples were air-dried and then passed through an $8 \mathrm{~mm}$ screen, with a $50 \mathrm{~g}$ subsample taken for water-stable aggregate analysis using a modified Yoder sieving machine with nested sieves of 2, 1 , 0.5 , and $0.25 \mathrm{~mm}$ screen sizes (Kemper and Rosenau 1986). The remainder of each sample was passed through a $2 \mathrm{~mm}$ screen. Soil $\mathrm{pH}$ and $\mathrm{EC}$ were measured on a 1:1 soil to water basis. Sodium bicarbonate $\left(\mathrm{NaHCO}_{3}\right)$ extractable soil P (Olsen et al. 1954) was analyzed via continuous flow analyzer (Lachat Instruments, Loveland, Colorado). Although inorganic $\mathrm{N}$ levels and available micronutrients are not directly included in the SMAF framework, these values were of interest to 
Table 1

Annual manure application rates (dry weight basis) and estimated total and extractable (i.e., available) nutrients applied with manure (dry weight basis). No manure was applied in 2016.

\begin{tabular}{|c|c|c|c|c|c|c|}
\hline \multirow[b]{3}{*}{ Nutrient } & \multicolumn{6}{|c|}{ Year and application rate $\left(\mathrm{Mg} \mathrm{ha}^{-1}\right)$} \\
\hline & 2012 & 2013 & 2014 & 2015 & 2017 & 2018 \\
\hline & 52.9 & 33.6 & 36.8 & 36.1 & 51.6 & 51.6 \\
\hline Total C $\left(\mathrm{kg} \mathrm{ha}^{-1}\right)$ & 7,500 & 4,880 & 5,330 & 4,260 & 6,600 & 4,810 \\
\hline Total N (kg ha $\left.{ }^{-1}\right)$ & 467 & 348 & 406 & 408 & 466 & 384 \\
\hline $\mathrm{NO}_{3}-\mathrm{N}\left(\mathrm{kg} \mathrm{ha}^{-1}\right)$ & 2.9 & 0.4 & 0.1 & 23.1 & 0.6 & 1.7 \\
\hline $\mathrm{NH}_{4}-\mathrm{N}\left(\mathrm{kg} \mathrm{ha}^{-1}\right)$ & 10.7 & 4.0 & 3.3 & 1.0 & 1.4 & 2.0 \\
\hline Total P $\left(\mathrm{kg} \mathrm{ha}^{-1}\right)$ & 257 & 140 & 147 & 254 & 115 & 103 \\
\hline Total K $\left(\mathrm{kg} \mathrm{ha}^{-1}\right)$ & 577 & 459 & 448 & 473 & 301 & 313 \\
\hline Total Cu (kg ha $\left.{ }^{-1}\right)$ & 2.5 & 1.3 & 1.5 & 1.8 & 1.4 & 1.2 \\
\hline Available $\mathrm{Cu}\left(\mathrm{kg} \mathrm{ha}^{-1}\right)$ & 1.1 & 0.4 & 0.5 & 0.4 & 0.7 & 0.9 \\
\hline Total Mn $\left(\mathrm{kg} \mathrm{ha}^{-1}\right)$ & 11.6 & 7.4 & 7.5 & 9.5 & 7.0 & 5.8 \\
\hline Available $\mathrm{Mn}\left(\mathrm{kg} \mathrm{ha}^{-1}\right)$ & 1.6 & 0.7 & 1.0 & 1.8 & 1.2 & 1.6 \\
\hline Total Zn (kg ha-1) & 8.8 & 4.9 & 4.7 & 8.6 & 4.8 & 3.4 \\
\hline Available Zn $\left(\mathrm{kg} \mathrm{ha}^{-1}\right)$ & 3.6 & 2.5 & 2.8 & 2.8 & 2.9 & 3.1 \\
\hline Total Fe $\left(\mathrm{kg} \mathrm{ha}^{-1}\right)$ & 548 & 333 & 225 & 402 & 261 & 252 \\
\hline Available Fe (kg ha-1) & 7 & 4.1 & 3.6 & 3.0 & 4.0 & 5.2 \\
\hline
\end{tabular}

Notes: $\mathrm{C}=$ carbon. $\mathrm{N}=$ nitrogen. $\mathrm{P}=$ phosphorus. $\mathrm{K}=$ potassium. $\mathrm{NO}_{3}-\mathrm{N}=$ nitrate nitrogen. $\mathrm{NH}_{4}-\mathrm{N}$

$=$ ammoniacal nitrogen. $\mathrm{Cu}=$ copper. $\mathrm{Mn}=$ manganese. $\mathrm{Zn}=$ zinc. $\mathrm{Fe}=$ iron .

this study due to their impact on plant growth and crop productivity. Soil $\mathrm{NO}_{3}$ and $\mathrm{NH}_{4}$ were measured via continuous flow analyzer after extraction with $2 \mathrm{M} \mathrm{KCl}$. Available soil $\mathrm{Zn}$, manganese $(\mathrm{Mn}), \mathrm{Fe}$, copper $(\mathrm{Cu})$, $\mathrm{K}$, and magnesium $(\mathrm{Mg})$ were analyzed via inductively coupled plasma optical emission spectrometry (ICP-OES) after diethylenetriaminepentaacetic acid (DTPA) extraction (Lindsay and Norvell 1978). Samples for total soil C (TSC) and total soil N (TSN) analyses were further ground to pass a $150 \mathrm{um}$ screen before analysis (Elementar Americas Inc., Mt. Laurel, New Jersey). Soil inorganic carbon (SIC) was determined via pressure calcimeter (Sherrod et al. 2002). Soil organic carbon was calculated as the difference between TSC and SIC. $\beta$-Glucosidase (BG) activity was assayed using the methods of Eivazi and Tabatabai (1988). Potentially mineralizable N (PMN) was measured via a 28 day incubation-net mineralized $\mathrm{N}$ was calculated by subtracting the baseline mineral $\mathrm{N}$ from mineral $\mathrm{N}$ val-

\section{Table 2}

Chemical and nutrient characteristics of manure by year. Only one composite sample was analyzed in 2012, except for carbon (C) and nitrogen (N). Values for all other years represent the average values from four sample analyses, and numbers in parentheses represent the standard deviation. Each of the four samples was aggregated from four subsamples taken from the manure applied to each field plot replicate. No manure was applied in 2016.

\begin{tabular}{|c|c|c|c|c|c|c|}
\hline \multirow[b]{3}{*}{ Nutrient } & \multicolumn{6}{|c|}{ Year and application rate (Mg ha-1) } \\
\hline & 2012 & 2013 & 2014 & 2015 & 2017 & 2018 \\
\hline & 52.9 & 33.6 & 36.8 & 36.1 & 51.6 & 51.6 \\
\hline Total C (\%) & $14.5(2.3)$ & $14.5(1.9)$ & $14.4(1.5)$ & $11.8(0.9)$ & $12.7(1.7)$ & $9.3(1.1)$ \\
\hline Total N (\%) & $0.90(0.14)$ & $1.03(0.12)$ & $1.10(0.10)$ & $1.13(0.08)$ & $0.90(0.10)$ & $0.74(0.08)$ \\
\hline Total P (\%) & 0.48 & $0.42(0.08)$ & $0.40(0.03)$ & $0.70(0.01)$ & $0.22(0.03)$ & $0.20(0.01)$ \\
\hline Total K (\%) & 1.09 & $1.36(0.23)$ & $1.21(0.08)$ & $1.30(0.05)$ & $0.58(0.07)$ & $0.61(0.04)$ \\
\hline $\mathrm{NO}_{3}-\mathrm{N}\left(\mathrm{mg} \mathrm{kg}^{-1}\right)$ & 55 & $11.0(11)$ & $3.7(1.1)$ & $640(170)$ & $12.4(7.5)$ & $33.7(8.7)$ \\
\hline $\mathrm{NH}_{4}-\mathrm{N}\left(\mathrm{mg} \mathrm{kg}^{-1}\right)$ & 201.9 & $120(32)$ & $90.3(3.1)$ & $26.5(2.6)$ & $27(23)$ & $39.0(10.0)$ \\
\hline Exchangeable $\mathrm{Ca}\left(\mathrm{mg} \mathrm{kg}^{-1}\right)$ & 11,057 & * & * & $9,998(93)$ & $5,610(660)$ & $3,690(480)$ \\
\hline Water soluble $\mathrm{Ca}\left(\mathrm{mg} \mathrm{kg}^{-1}\right)$ & 299 & * & * & $282(9)$ & $1,068(97)$ & $326(19)$ \\
\hline Exchangeable $\mathrm{Mg}\left(\mathrm{mg} \mathrm{kg}^{-1}\right)$ & 2,896 & * & * & $2,704(83)$ & $1,284(150)$ & $450(55)$ \\
\hline Water soluble $\mathrm{Mg}\left(\mathrm{mg} \mathrm{kg}^{-1}\right)$ & 323 & * & * & $309(5)$ & $597(37)$ & $474(65)$ \\
\hline Total Cu $\left(\mathrm{mg} \mathrm{kg}^{-1}\right)$ & 46.9 & $37.4(4.9)$ & $39.4(2.8)$ & $49.8(0.6)$ & $27.5(4.3)$ & $22.8(2.1)$ \\
\hline Available Cu $\left(\mathrm{mg} \mathrm{kg}^{-1}\right)$ & 20.5 & $12.9(1.1)$ & $12.9(4.3)$ & $11.9(1.0)$ & $13.9(0.3)$ & $18.0(0.1)$ \\
\hline Total Mn $\left(\mathrm{mg} \mathrm{kg}^{-1}\right)$ & 218 & $218(18)$ & $203(63)$ & $263(1)$ & $135(17)$ & $112(4)$ \\
\hline Available $\mathrm{Mn}\left(\mathrm{mg} \mathrm{kg}^{-1}\right)$ & 30.3 & $21.8(2.0)$ & $27.8(8.5)$ & $51(29)$ & $22.8(1.0)$ & $30.5(0.4)$ \\
\hline Total Zn $\left(\mathrm{mg} \mathrm{kg}^{-1}\right)$ & 165 & $147(22)$ & $128(12)$ & $238(2)$ & $93(12)$ & $66(5)$ \\
\hline Available $\mathrm{Zn}\left(\mathrm{mg} \mathrm{kg}^{-1}\right)$ & 67.2 & $75.2(8.1)$ & $77(25)$ & $78.5(1.5)$ & $56.4(2.9)$ & $60.7(0.5)$ \\
\hline Total Fe $\left(\mathrm{mg} \mathrm{kg}^{-1}\right)$ & 10,330 & $9,880(890)$ & $6,100(460)$ & $11,080(150)$ & $5,030(3,000)$ & $4,860(530)$ \\
\hline Available Fe $\left(\mathrm{mg} \mathrm{kg}^{-1}\right)$ & 132 & $122(27)$ & $98(36)$ & $82.2(3.6)$ & $76.6(3.8)$ & $99.8(2.8)$ \\
\hline
\end{tabular}

Notes: $\mathrm{P}=$ phosphorus. $\mathrm{K}=$ potassium. $\mathrm{NO}_{3}-\mathrm{N}=$ nitrate nitrogen. $\mathrm{NH}_{4}-\mathrm{N}=$ ammoniacal nitrogen. $\mathrm{Ca}=$ calcium. $\mathrm{Mg}=$ magnesium. $\mathrm{Cu}=$ copper. $\mathrm{Mn}=$ manganese. $\mathrm{Zn}=$ zinc. $\mathrm{Fe}=$ iron.

*Exchangeable and water soluble Ca and Mg were not measured in 2013 and 2014. 
ues obtained after incubation (Drinkwater et al. 1996). Bulk density (BD) was determined via the core method on one sample taken within each replicated plot after harvest in fall of 2018.

Soil Management Assessment Framework. We utilized the SMAF tool to calculate physical, chemical, biological, nutrient, and overall $\mathrm{SH}$ indices for each treatment by soil depth. Unitless scores for each $\mathrm{SH}$ indicator range from 0 to 1 , with higher scores indicating "better" SH. Scoring curves are dependent on soil taxonomy and texture, temperature and rainfall regimes, slope, and crop. Scores for the indicators in each index are added together and divided by the numbers of indicators used to calculate that index (e.g., for the biological SH index, the indicator values for SOC (\%), PMN, and BG are added together and divided by three). The overall $\mathrm{SH}$ index is calculated by summing the scores for each $\mathrm{SH}$ index category, multiplying by 100 , and dividing by the total number of indicators. Full details of the SMAF algorithms are provided in Andrews et al. (2004) and Stott et al. (2010).

Plant Analyses. Aboveground biomass sampling occurred each year in late September at physiological maturity, prior to canopy senescence. Fifteen plants were harvested from a $1.5 \mathrm{~m}^{2}$ area within each plot. Plants were separated into grain (i.e., biomass grain), cobs, and stover (i.e., stalks plus leaves) and dried at $60^{\circ} \mathrm{C}$ for $>72$ hours for dry mass determination. Harvest grain yields were determined in late October by hand harvesting ears from an established plot area and separating the grain from the cob with a mechanical sheller. Final stover, cob, and harvest grain yields are expressed on an oven dry basis. Samples were dried and ground to pass a 150 um stainless steel screen and analyzed for $\mathrm{C}$ and $\mathrm{N}$ (Elementar Americas Inc., Mt. Laurel, New Jersey). Total macroand micronutrients in each plant fraction were determined via ICP-OES after nitric acid $\left(\mathrm{HNO}_{3}\right)$-hydrogen peroxide $\left(\mathrm{H}_{2} \mathrm{O}_{2}\right)$ digestion (Huang and Schulte 1985). The use of brackets [ ] around a nutrient denotes concentration. Each run included replicates and blanks, as well as replicates of certified plant standards (US National Institute of Standards). Total nutrient uptake in each plant compartment was calculated by multiplying biomass yields by nutrient concentrations.

Statistical Analysis. Soil data was analyzed separately for each depth using PROC
MIXED in SAS v.9.4 (SAS Institute 2013) to test the significance of amendment on $\mathrm{SH}$ indicators and SMAF indicator scores. Amendment was considered a fixed effect, and block replication considered random. For the plant and yield data, repeated measures analysis of variance (ANOVA) was used in PROC MIXED to analyze treatment effects over years. It is important to note that while the hybrids utilized in 2017 and 2018 were closely matched in traits, target environment, and relative maturity, with presumably very similar genetics given that they came from the same breeding program, we cannot rule out the possibility of genetic differences contributing to differences in nutrient concentrations between growing years (Grusak and DellaPenna 1999). While differences between growing years are discussed when significant, directional trends in nutrient concentrations were consistent between years unless otherwise noted, and results are averaged over the two site years. Statistical comparisons for all data were made at the $\alpha=0.05$ probability level using the LSD method for means separation.

\section{Results and Discussion}

Soil Quality Indicators. Soil $\mathrm{pH}$ in the 0 to $7.5 \mathrm{~cm}$ and 7.5 to $15 \mathrm{~cm}$ depths of the control and manure treatments were similar, averaging 8.3, whereas $\mathrm{pH}$ in the urea treatment was 0.3 units lower (figure 1a). Surface soil $\mathrm{pH}$ in the urea treatment likely declined due to acidity produced following urea application (Havlin et al. 2005).

Soil EC in the surface 0 to $7.5 \mathrm{~cm}$ was $0.4 \mathrm{dS} \mathrm{m}^{-1}$ higher in the urea treatment than in the control and manure treatments (figure 1b). Soil EC measures the total concentration of soluble salts in solution, and the increase in EC in the urea treatment is likely due to higher soil nitrate $\left(\mathrm{NO}_{3}^{-}\right)$(figure $3 \mathrm{a}$ ). Manure can contain large amounts of salts, which can in some cases increase EC and negatively impact plant growth via water and ion imbalances. However, multiple studies have reported only nominal changes in soil EC after repeated years of manure application (i.e., $<0.5 \mathrm{dS} \mathrm{m}^{-1}$ ) (Calderon et al. 2018; Eghball et al. 2004; Schlegel et al. 2017), and our results similarly indicate that manure application does not necessarily negatively impact soil EC. In addition, the general EC thresholds wherein maize yields are impacted are well above the EC levels we measured. Previously published salinity tolerance indi- ces for maize developed under greenhouse conditions with chloride salts indicated initial yield declines at $\geq 1.70 \mathrm{dS} \mathrm{m}^{-1}$ (Maas and Hoffman 1977). However, recent work in field maize utilizing natural gradients of salinity found no declines in growth at EC values $>9 \mathrm{dS} \mathrm{m}^{-1}$ (Butcher et al. 2018), indicating that tolerance thresholds in the SMAF framework may need to be reevaluated or calibrated for additional soils.

Manure amendment increased SOC (\%) and TSN (\%) in the surface 0 to $7.5 \mathrm{~cm}$ and 7.5 to $15 \mathrm{~cm}$ depths compared to the control and urea treatments, with no differences in the 15 to $30 \mathrm{~cm}$ depth (figure $2 \mathrm{a}$ ). Due to the near-total aboveground biomass removal from silage harvest, the majority of $\mathrm{C}$ returned to the soil is root derived or via manure. Halvorson et al. (2016) reported increases in SOC and TSN in this system after three years of manure application, whereas SOC and TSN decreased or remained constant in the urea and control treatments. Manure contains large amounts of $\mathrm{C}$ and $\mathrm{N}$ (table 1), and increases in SOC and TSN following manure addition are well documented (Maillard and Angers 2014), underscoring the role manure can play in restoring or building SOC and TSN and overall $\mathrm{SH}$

Manure amendment increased BG activity by up to $50 \%$ in the 0 to $7.5 \mathrm{~cm}$ and 7.5 to $15 \mathrm{~cm}$ depth (figure $2 \mathrm{c}$ ). In the 7.5 to 15 $\mathrm{cm}$ depth, BG activity of the urea treatment was higher than the control, likely due to increased root-derived $\mathrm{C}$ inputs. No treatment differences were detected in the 15 to $30 \mathrm{~cm}$ depth. $\beta$-glucosidase activity is a sensitive indicator of soil metabolic activity and $\mathrm{C}$ cycling - our results agree with other studies that have found that manure amendments increase BG activity (Acosta-Martinez et al. 2011; Calderon et al. 2018; Garcia-Gil et al. 2000).

Potentially mineralizable $\mathrm{N}$ was higher in the urea and manure treatments than in the control in all three soil depths (figure $2 \mathrm{~d})$. Immobilization of $\mathrm{N}$ was evident in the control treatment (i.e., the conversion of inorganic $\mathrm{N}$ to organic $\mathrm{N}$ ) for all three soil depths, reflecting the low inorganic $\mathrm{N}$ levels after seven years of no $\mathrm{N}$ fertilization.

There were no treatment differences in water-stable aggregates $>250 \mu \mathrm{m}$ at any depth (data not shown). While some studies have found increases in macroaggregates with manure application, these studies are often 


\section{Figure 1}

(a) Soil pH and (b) electrical conductivity by soil depth and treatment (control $=0 \mathrm{~kg} \mathrm{~N} \mathrm{ha}^{-1}$, urea $=179 \mathrm{~kg} \mathrm{~N} \mathrm{ha}^{-1}$, and manure $=$ target application rate of $\left.179 \mathrm{~kg} \mathrm{~N} \mathrm{ha}^{-1}\right)$. Error bars represent the standard error of the mean $(n=4)$. Values within soil depth marked with different letters are significantly different at $\alpha=0.05$.

\section{(a)}

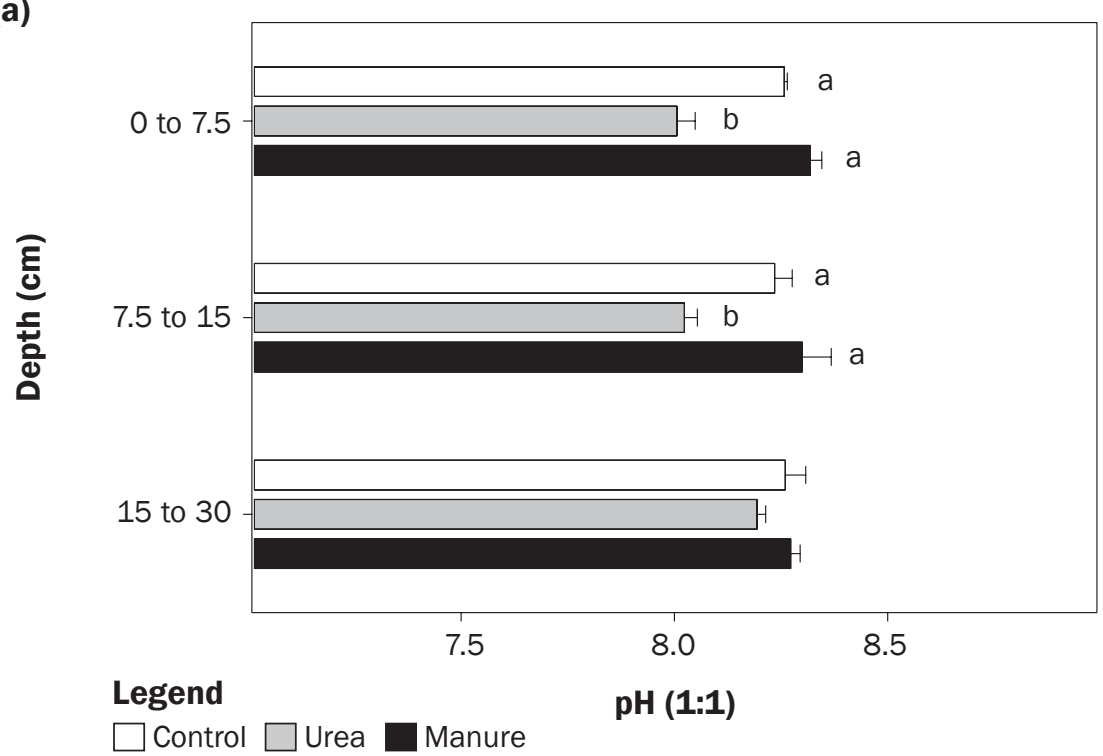

(b)

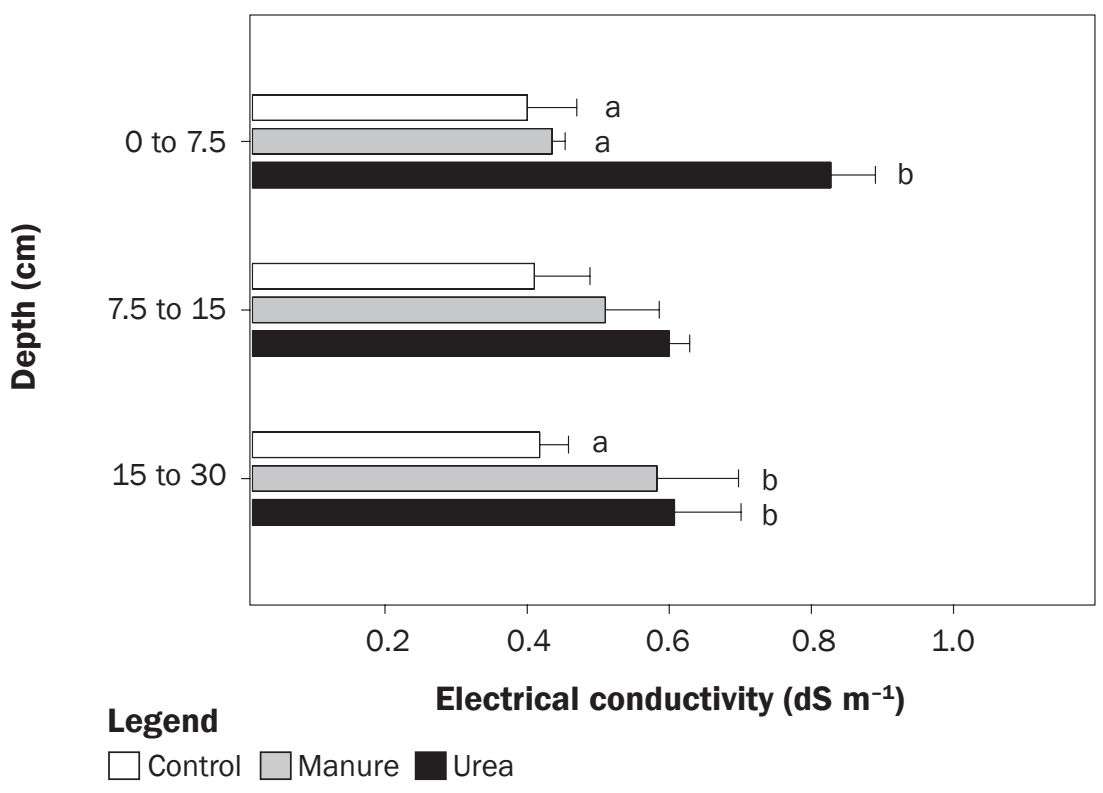

of longer duration. For example, Aoyama et al. (1999) and Mikha et al. (2015) reported increases in macro-aggregation after 18 and 70 years of manure application, respectively. Irrigated semiarid systems also appear to have relatively low levels of macroaggregation (Gillabel et al. 2007). In addition, tillage can disrupt or prevent the formation of sta- ble macroaggregates (Mikha and Rice 2004; Six et al. 2000), and annual tillage events in this system may have minimized the positive impacts of manure amendments.

Despite the large input of lower density organic matter (OM) via manure application, there were no treatment differences in BD at any depth (data not shown). These findings concur with those of Eghball (2002), who also reported no changes in BD with multiple manure applications in a similar system characterized by high clay content and low OM.

Soil Macronutrients. The bulk of inorganic soil $\mathrm{N}$ was in the form of nitrate nitrogen $\left(\mathrm{NO}_{3}-\mathrm{N}\right)$ (figure 3a); ammoniacal nitrogen $\left(\mathrm{NH}_{4}-\mathrm{N}\right)$ was $<8 \mathrm{mg} \mathrm{kg}^{-1}$ in all depths and did not vary between treatments (data not shown). $\mathrm{NO}_{3}-\mathrm{N}$ was markedly higher in the urea treatment in all depths, ranging from 88 $\mathrm{mg} \mathrm{kg}^{-1}$ in the surface 0 to $7.5 \mathrm{~cm}$ to 39.9 $\mathrm{mg} \mathrm{kg}^{-1}$ in the 15 to $30 \mathrm{~cm}$ depth. Sampling occurred shortly after urea was applied, and hence these values reflect the high available $\mathrm{N}$ at emergence in this treatment. $\mathrm{NO}_{3}-\mathrm{N}$ levels were not different between the control and manure treatments, ranging from 7.2 to $19.8 \mathrm{mg} \mathrm{kg}^{-1}$, levels considered limiting to maize production (Davis et al. 2009).

Soil test P (STP) levels did not differ between the control and urea treatments at any soil depth; STP in the 0 to $7.5 \mathrm{~cm}$ and 7.5 to $15 \mathrm{~cm}$ depths ranged from 12.3 to $20.7 \mathrm{mg} \mathrm{kg}^{-1}$ (figure 3b). Concentrations of 15 to $22 \mathrm{mg} \mathrm{P} \mathrm{kg}^{-1}$ are considered high in Colorado soils, wherein yield responses to additional $\mathrm{P}$ are unlikely (Davis et al. 2009). However, in the 15 to $30 \mathrm{~cm}$ depth, STP in the control and urea treatments was $<3 \mathrm{mg} \mathrm{kg}^{-1}$, well below sufficiency levels. These results indicate that despite multiple broadcast $\mathrm{P}$ applications, STP was below sufficiency in much of the rooting zone (i.e., depths below $15 \mathrm{~cm}$ ) of the urea and control treatments due to low P mobility (Eghball et al. 1990). Manure application increased STP in all soil depths, where concentrations were $\sim 500 \%$ higher than the control and urea treatments. Soil test $\mathrm{P}$ concentrations in the manure treatment were as high as $93.9 \mathrm{mg}$ $\mathrm{kg}^{-1}$ in the surface 0 to $7.5 \mathrm{~cm}$. Soil $\mathrm{P}$ levels in the 15 to $30 \mathrm{~cm}$ depth of the manure treatment were adequate, averaging $13.8 \mathrm{mg}$ $\mathrm{kg}^{-1}$, indicating either movement of dissolved $\mathrm{P}$ from surface depths or enhanced P solubility due to chemical reaction of $\mathrm{P}$ with manure compounds (Eghball et al. 1996; Eghball et al. 2003).

These findings agree with previous studies demonstrating STP buildup with manure application (Eghball and Power 1999b; Halvorson et al. 2016; Schlegel et al. 2017). Schlegel et al. (2017) reported a buildup of STP after three years of $\mathrm{N}$-based manure application to an alkaline soil (i.e., Olsen P 


\section{Figure 2}

(a) Soil organic carbon (C), (b) total soil nitrogen (N), (c) $\beta$-glucosidase (BG) enzyme activity, (d) potentially mineralizable N, (e) water-stable macroaggregate fraction, and (f) bulk density by soil depth and treatment (control $=0 \mathrm{~kg} \mathrm{~N} \mathrm{ha}{ }^{-1}$, urea $=179 \mathrm{~kg} \mathrm{~N} \mathrm{ha}^{-1}$, and manure $=$ target application rate of $\left.179 \mathrm{~kg} \mathrm{~N} \mathrm{ha}^{-1}\right)$. Error bars represent the standard error of the mean $(n=4)$. Values within soil depth marked with different letters are significantly different at $\alpha=0.05$.

(a)

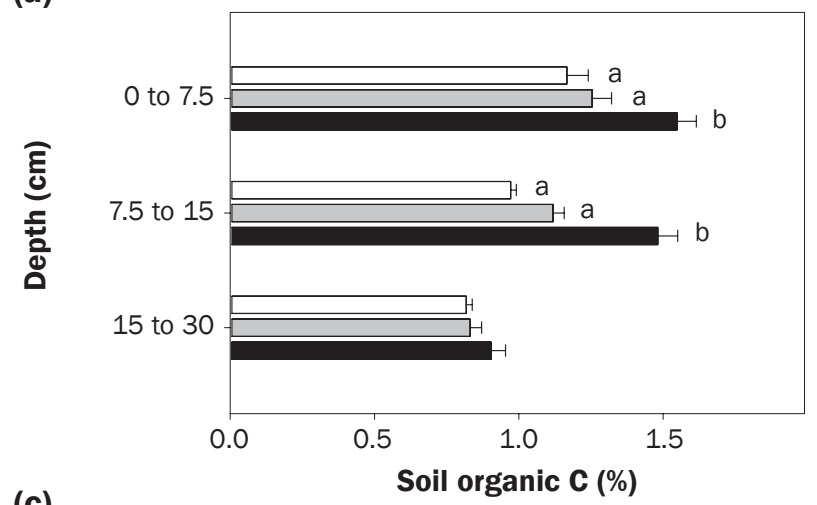

(c)

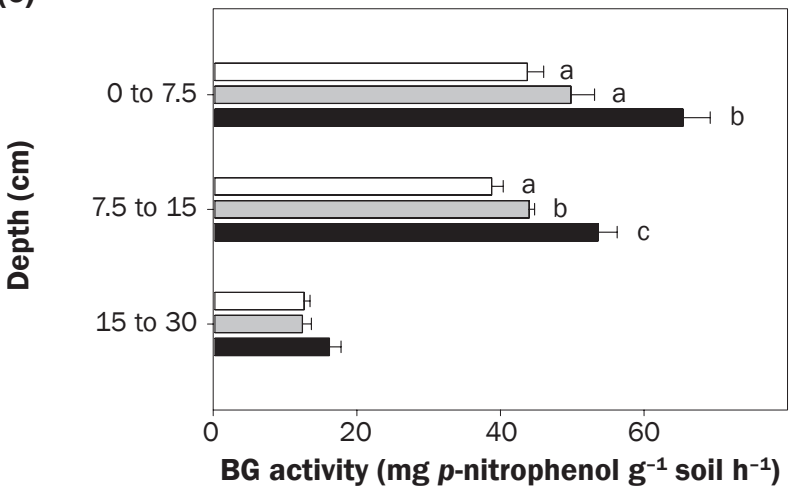

(e)

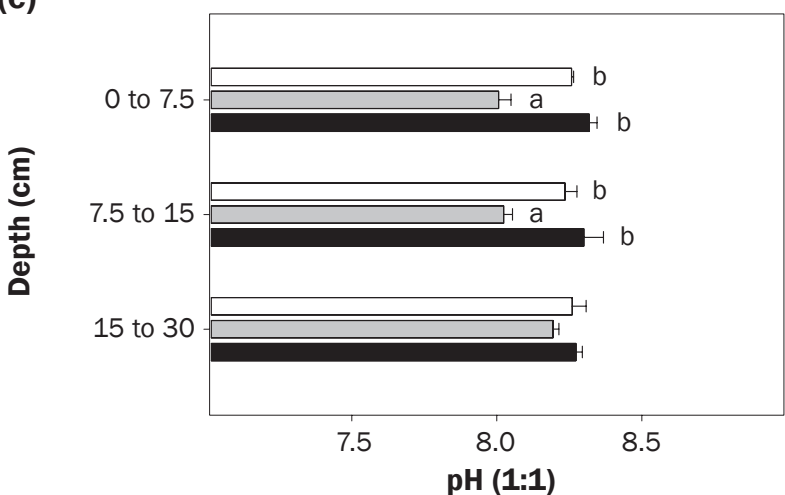

Legend

$\varpi$ Control $\square$ Urea Manure

levels of $\left.>100 \mathrm{mg} \mathrm{kg}^{-1}\right)$; however, after 10 application years there was no additional evidence suggesting additional STP buildup had occurred. Previously at this study site, Halvorson et al. (2016) reported that fall STP levels in the surface 0 to $15 \mathrm{~cm}$ increased with manure addition, with STP concentrations (b)

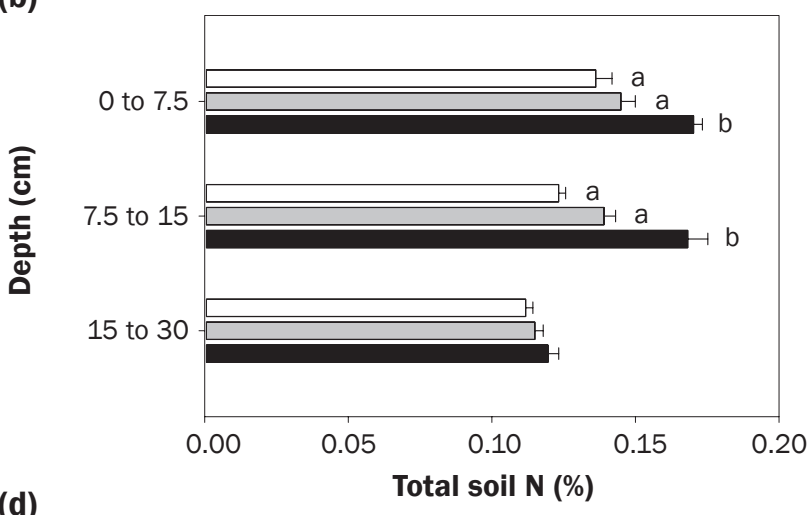

(d)

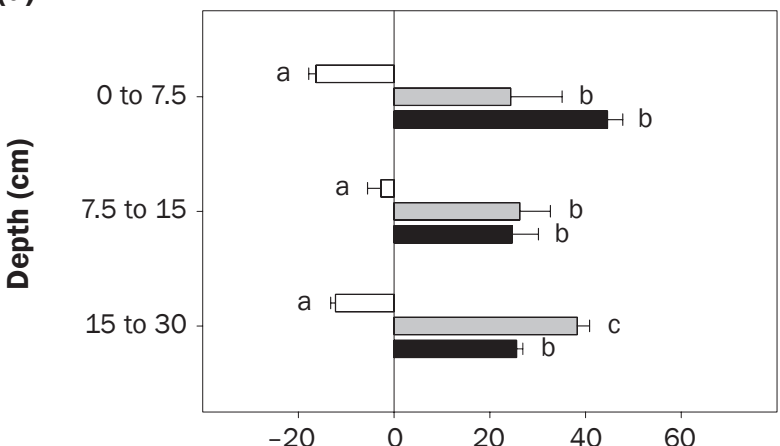

Potentially mineralizable $\mathbf{N}$ (mg N kg soil- ${ }^{-1}$ )

(f)

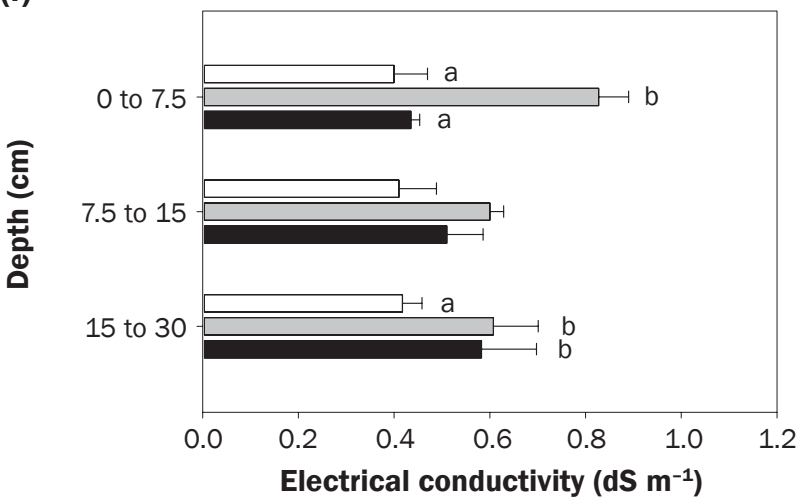

of $>110 \mathrm{mg} \mathrm{kg}^{-1}$ after three years of application (i.e., 2012 to 2014). The fact that spring postmanure application STP concentrations in 2018 did not increase beyond those reported for 2014 is surprising. In 2016, no manure was applied, which may have drawn down STP.The lack of additional increases in
STP over time likely indicates soil P sorption into unavailable forms (Eghball et al. 2005). The influence of applied P on STP is dependent on initial P concentrations, application rates, sorption processes, and soil $\mathrm{P}$ saturation (Hansen et al. 2002). A large proportion of manure-borne $\mathrm{P}$ is inorganic, resulting in 


\section{Figure 3}

(a) Soil nitrate nitrogen ( $\mathrm{NO}_{3}-\mathrm{N}$ ), (b) Olsen phosphorus, and (c) diethylenetriaminepentaacetic (DTPA) potassium by soil depth and treatment (control $=0 \mathrm{~kg} \mathrm{~N} \mathrm{ha}{ }^{-1}$, urea $=179 \mathrm{~kg} \mathrm{~N} \mathrm{ha}^{-1}$, and manure $=$ target application rate of $179 \mathrm{~kg} \mathrm{~N} \mathrm{ha}^{-1}$ ). Error bars represent the standard error of the mean $(n=4)$. Values within soil depth marked with different letters are significantly different at $\alpha=0.05$.

(a)

(b)
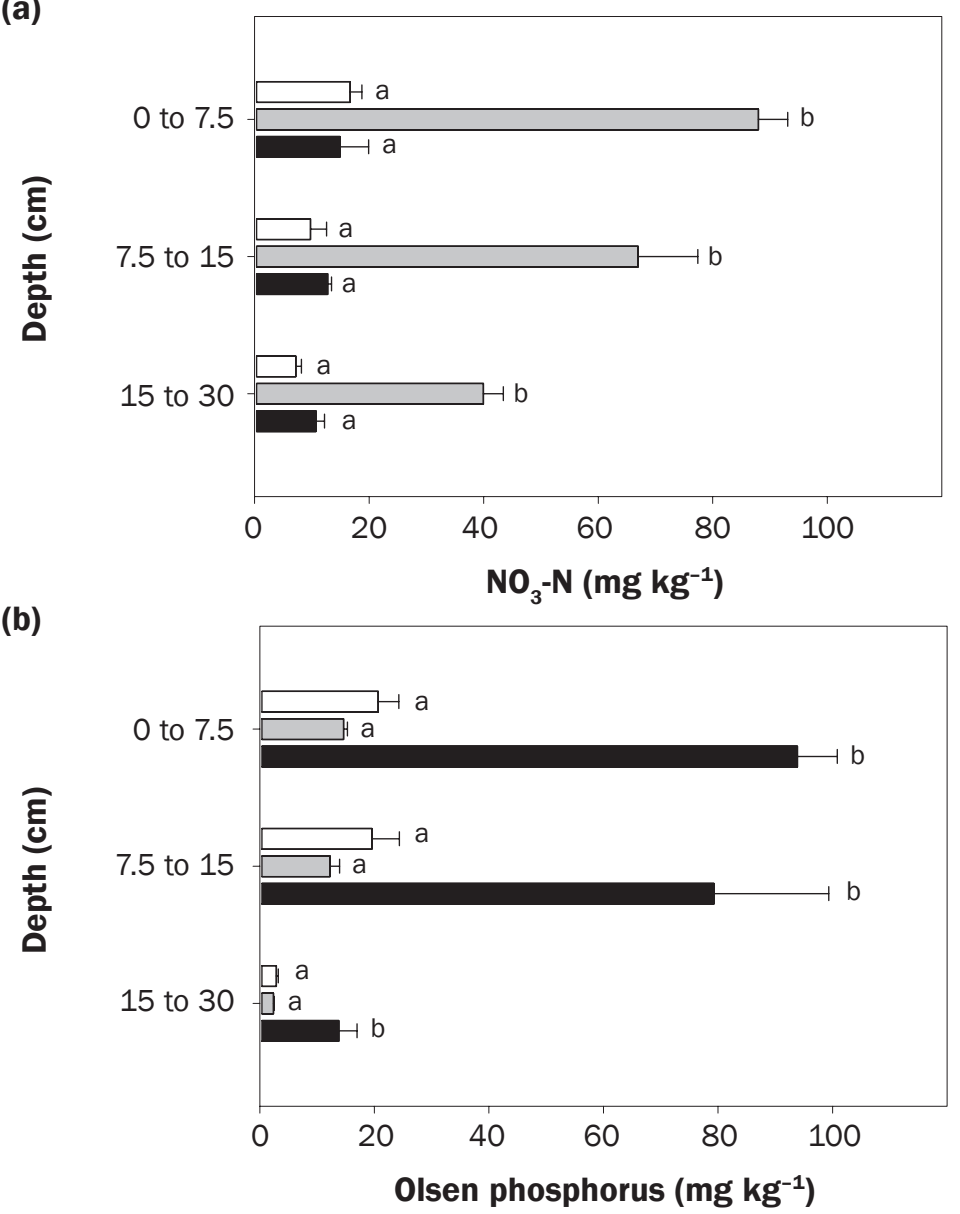

(c)

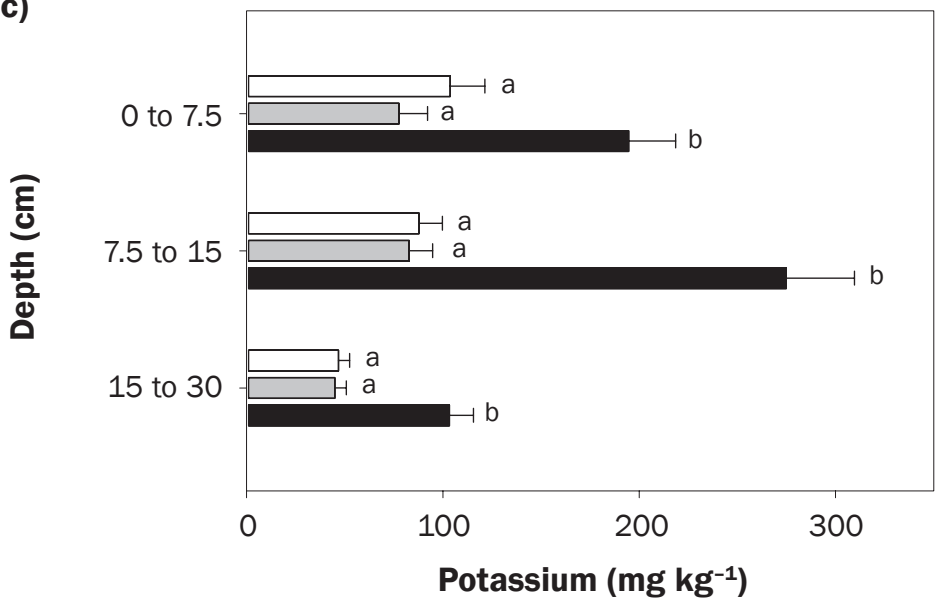

Legend

$\square$ Control $\square$ Urea $\square$ Manure high P availability after application; however, $\mathrm{P}$ availability is a function of soil $\mathrm{P}$ sorptivity (Hansen et al. 2002). It is likely that $\mathrm{P}$ sorption processes (i.e., $\mathrm{P}$ adsorption to mineral surfaces and $\mathrm{P}$ precipitation) are high in this system due to high clay, $\mathrm{pH}$, and calcium carbonate $\left(\mathrm{CaCO}_{3}\right)$ contents. Phosphorus adsorption increases with clay content; in calcareous soils, high concentrations of $\mathrm{Ca}_{2}{ }^{+}$ in the soil solution, coupled with high $\mathrm{pH}$, promotes the precipitation of calcium phosphates $\left(\mathrm{Ca}_{3}\left(\mathrm{PO}_{4}\right)_{2}\right)$, depressing phosphate $\left(\mathrm{PO}_{4}{ }^{3-}\right)$ availability (Eghball 2002; Eghball et al. 2005). The adsorption and immobilization of $\mathrm{P}$ by $\mathrm{CaCO}_{3}$ is especially rapid in calcareous soils (Mengel and Kirkby 1982). Overapplication of $\mathrm{P}$ carries multiple environmental risks of $\mathrm{P}$ losses via runoff or leaching; however, the high clay, high $\mathrm{pH}$, calcareous soils of this region, coupled with distance from large water bodies, may reduce the environmental risk compared to other agricultural regions.

Soil K concentrations were higher in the manure treatment than in the control and urea treatments in all depths (figure 3c). Manure contains large amounts of $\mathrm{K}$, and over the course of six years, $\sim 2,500 \mathrm{~kg} \mathrm{~K} \mathrm{ha}^{-1}$ were applied via manure (table 1). Potassium contained in manure is estimated to be $100 \%$ plant available, and increases in soil $\mathrm{K}$ with manure application are frequently reported (Eghball et al. 2002; Lentz and Ippolito 2012; Schlegel et al. 2017; Vitosh et al. 1973). However, most Colorado soils are inherently high in extractable $\mathrm{K}$, and very few growth responses to $\mathrm{K}$ fertilization have been reported.

Soil Micronutrients. Available soil $\mathrm{Cu}$ $\left(\mathrm{Cu}_{\text {vvii }}\right)$ ranged from 0.91 to $1.90 \mathrm{mg} \mathrm{kg}{ }^{-1}$ between treatments (figure 4a), well above the critical threshold of $0.2 \mathrm{mg} \mathrm{kg}^{-1}$ identified for maize (Lindsay and Norvell 1978). Treatment differences were evident only in the 7.5 to $15 \mathrm{~cm}$ depth, where $\mathrm{Cu}_{\text {avil }}$ in the manure treatment was higher than the urea treatment, but not different from the control $(p=0.07)$. Estimated total $\mathrm{Cu}$ applied annually in manure ranged from 1.2 to $2.5 \mathrm{~kg} \mathrm{ha}^{-1}$, but less than half of total $\mathrm{Cu}$ was estimated to be available (table 1). Most $\mathrm{Cu}_{\text {avail }}$ in calcareous soils is present as organic complexes, with soluble OM controlling the amount of complexed $\mathrm{Cu}$ in soil solution (Hodgson et al. 1966; McLaren and Crawford 1973). Manure application likely synergistically increases $\mathrm{Cu}_{\text {avail }}$ via increased $\mathrm{Cu}$ inputs, as well as promotion of $\mathrm{Cu}$ com- 


\section{Figure 4}

(a) Soil diethylenetriaminepentaacetic (DTPA) extractable copper, (b) iron, (c) manganese, and (d) zinc by soil depth and treatment (control = o kg N $\mathrm{ha}^{-1}$, urea $=179 \mathrm{~kg} \mathrm{~N} \mathrm{ha}^{-1}$, and manure $=$ target application rate of $\left.179 \mathrm{~kg} \mathrm{~N} \mathrm{ha}^{-1}\right)$. Error bars represent the standard error of the mean $(n=4)$. Values within soil depth marked with different letters are significantly different at $\alpha=0.05$.

(a)

(c)
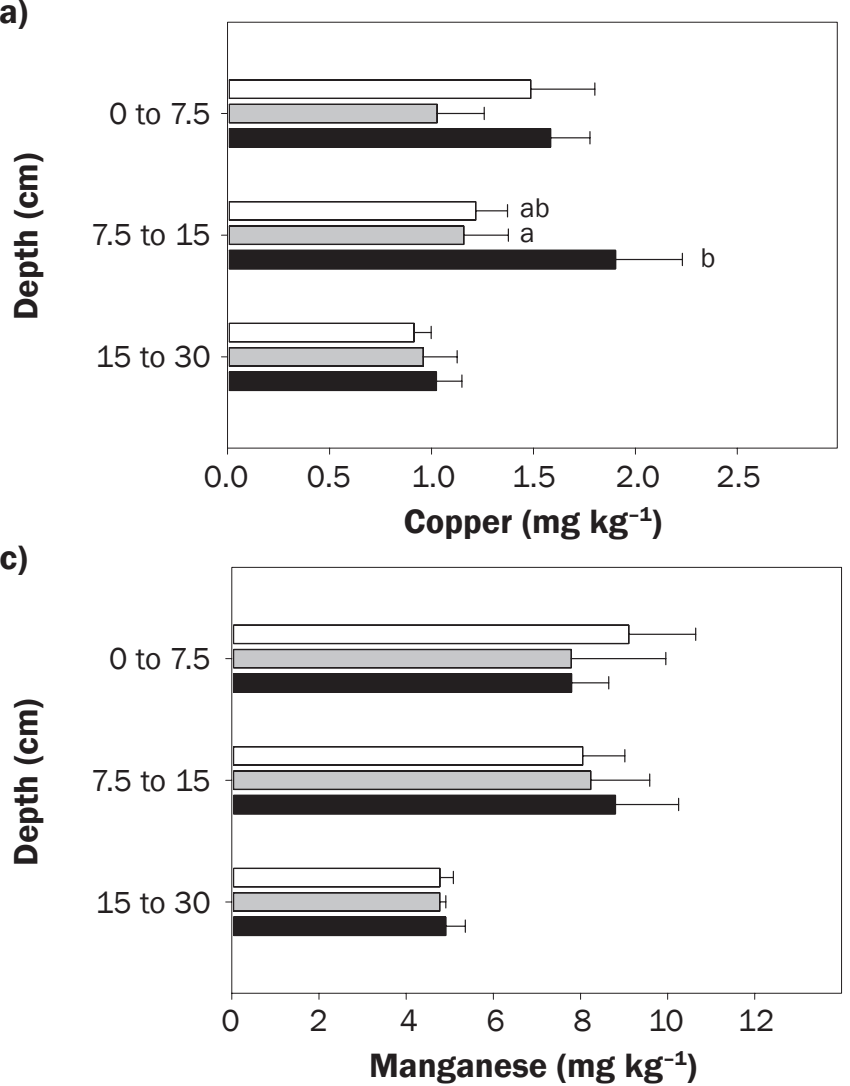

(b)

0 to

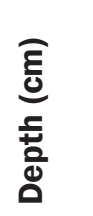

7.5 to 15

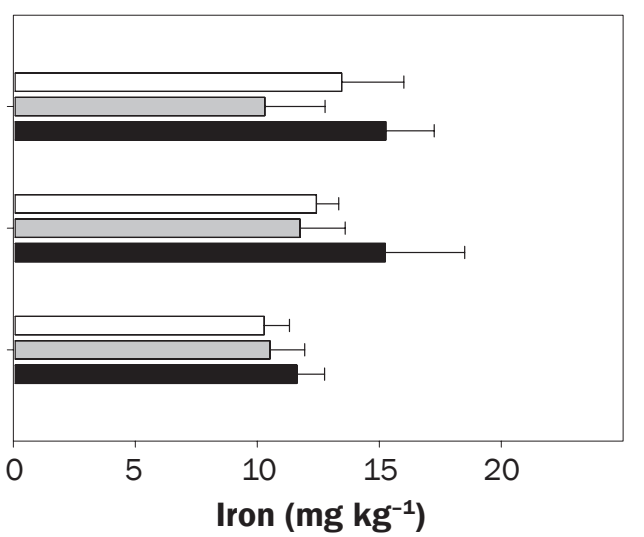

(d)

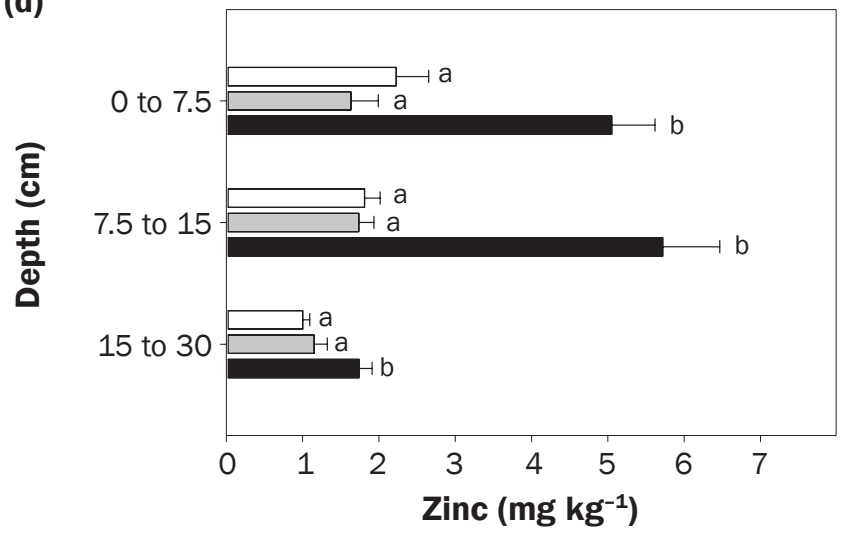

Legend

$\square$ Control $\square$ Urea $\square$ Manure

plexing via increased OM. Others have also found increases in total and available $\mathrm{Cu}$ after manure application (Kornegay et al. 1976; Lentz and Ippolito 2012; Schlegel et al. 2017).

Available soil $\mathrm{Fe}\left(\mathrm{Fe}_{\text {avii }}\right)$ ranged from 10.2 to $15.3 \mathrm{mg} \mathrm{kg}^{-1}$ (figure $4 \mathrm{~d}$ ). Iron availability in alkaline soils is sometimes limiting, yet $\mathrm{Fe}_{\text {avail }}$ levels were above sufficiency levels of $4.5 \mathrm{mg}$ $\mathrm{kg}^{-1}$ (Lindsay and Norvell 1978). Although manure Fe content is infrequently reported, others have reported manure $\mathrm{Fe}$ of $\approx 0.5 \%$ (Lentz and Ippolito 2012), and in our analysis Fe concentrations ranged from $\approx 0.5 \%$ to $1 \%$ (table 2). Despite the annual addition of 225 to $550 \mathrm{~kg} \mathrm{ha}^{-1}$ of total Fe with manure, there were no treatment differences in $\mathrm{Fe}_{\text {avil }}$ after six years of manure application (figure 4b). These results agree with other studies that have similarly reported no changes in $\mathrm{Fe}_{\text {avail }}$ after manure application (Lentz and Ippolito
2012; Schlegel et al. 2017). Most soils have a high abundance of total $\mathrm{Fe}$, but at high soil $\mathrm{pH}, \mathrm{Fe}$ is rapidly precipitated as $\mathrm{Fe}$ oxide and has very limited solubility (Lindsay and Schwab 1982), which likely explains the lack of treatment differences.

Available soil $\mathrm{Mn}\left(\mathrm{Mn}_{\text {avail }}\right)$ ranged from 4.8 to $9.1 \mathrm{mg} \mathrm{kg}^{-1}$ (figure $4 \mathrm{c}$ ), well above the suggested sufficiency thresholds of $1.2 \mathrm{mg}$ $\mathrm{kg}^{-1}$ (Lindsay and Norvell 1978). Despite the addition of an estimated $50 \mathrm{~kg} \mathrm{Mn} \mathrm{ha}{ }^{-1}$ in manure over six years (table 1), there were no treatment differences in $\mathrm{Mn}_{\text {avail }}$. Other studies have also failed to find consistent increases in $\mathrm{Mn}_{\text {avail }}$ with manure application (Lentz and Ippolito 2012; Schlegel et al. 2017). Lentz and Ippolito (2012) reported a 1.4-fold increase in $\mathrm{Mn}_{\text {avail }}$ after a one-time manure application in the first growing season but could detect no differences relative to the control in the second season. Although increases in
OM can increase solution and exchangeable $\mathrm{Mn}$ via chelation, adsorption and retention of $\mathrm{Mn}$ increases with increasing $\mathrm{pH}$, clay, and SOM content, and $\mathrm{Mn}_{\text {avail }}$ in the manure was likely adsorbed upon incorporation (Khattak and Page 2017; Mandal and Mitra 1982).

Available soil $\mathrm{Zn}\left(\mathrm{Zn}_{\text {avail }}\right)$ ranged from 1 to $2 \mathrm{mg} \mathrm{kg}^{-1}$ in the check and urea treatments to as high as $5.7 \mathrm{mg} \mathrm{kg}^{-1}$ in the manure treatment (figure 4d). Levels of 1 to $1.5 \mathrm{mg}$ $\mathrm{kg}^{-1}$ are considered marginal for maize, with $>1.5 \mathrm{mg} \mathrm{kg}^{-1}$ considered adequate (Davis et al. 2009). An estimated $35 \mathrm{~kg} \mathrm{ha}^{-1}$ of $\mathrm{Zn}$ was applied over the course of six years with manure, with $\sim 50 \%$ estimated to be plant available (table 1). Zinc availability increased by $130 \%$ to $230 \%$ in the 0 to $7.5 \mathrm{~cm}$ and 7.5 to $15 \mathrm{~cm}$ depths with manure compared to the control or urea treatments. These results are consistent with other studies that have reported increases in $\mathrm{Zn}_{\text {avail }}$ with manure 
application (Schlegel et al. 2017). In addition, $\mathrm{Zn}_{\text {avail }}$ increased in the 15 to $30 \mathrm{~cm}$ depth, whereas the tillage operations in this system incorporate the manure only to 0 to $15 \mathrm{~cm}$. These results suggest that $\mathrm{Zn}$ is leaching or moving in the soil profile when organic matter (manure) is added into the surface soil. Similar responses suggestive of $\mathrm{Zn}$ movement were found by Miner et al. (2018), who reported that $\mathrm{Zn}_{\text {avail }}$ increased in surface and subsurface soil depths after conversion to a no-till system increased surface soil C. Other authors have reported $\mathrm{Zn}$ movement in the soil profile with manure application (Asada et al. 2010; Jalali and Khanboluki 2007). $\mathrm{Zn}_{\text {avail }}$ is frequently low or limiting in alkaline soils — an estimated $50 \%$ of soils cultivated globally for cereal production are low in $\mathrm{Zn}_{\text {avail }}$ (Cakmak 2002), underscoring that increases in $\mathrm{Zn}_{\text {avail }}$ with manure would be highly beneficial in many cropping systems.

Soil Management Assessment Framework Soil Quality Indices. Physical, chemical, biological, nutrient, and overall $\mathrm{SH}$ indicator scores for the 0 to $7.5 \mathrm{~cm}$ and 7.5 to $15 \mathrm{~cm}$ depths are presented in figure 5 . No differences were found in the 15 to $30 \mathrm{~cm}$ depth for SMAF indicators, except for in EC and PMN, so SMAF data are not presented for this depth.

The physical SH index scores in the 0 to $7.5 \mathrm{~cm}$ and 7.5 to $15 \mathrm{~cm}$ depths were $\geq 0.8$ and did not differ between treatments. The physical SH index includes BD and aggregation, which did not change with treatment. The chemical SH index, which includes EC and $\mathrm{pH}$, was greater in the urea treatment in both depths compared to the control or manure treatments, mainly due to lower soil $\mathrm{pH}$. The three treatments separated with respect to biological $\mathrm{SH}$ due to the higher SOC and BG activity in the manure treatment and the higher mineralized $\mathrm{N}$ in the manure and urea treatments (figure 2). Despite the high STP levels in the manure treatment, the nutrient $\mathrm{SH}$ index was still $\sim 0.8$ and did not separate out from the urea and control treatments. The overall $\mathrm{SH}$ index for urea and manure treatments was higher than the control, but there were no differences between the urea and manure treatments, indicating no additional increases in overall SH despite the large inputs of OM and nutrients via manure.

The SMAF index rankings support the conclusion that adding manure and $\mathrm{N}$ fertilizer improves $\mathrm{SH}$ in this system. The

\section{Figure 5}

Physical, chemical, biological, nutrient, and overall soil quality indices in the surface (a) o to $7.5 \mathrm{~cm}$ and (b) 7.5 to $15 \mathrm{~cm}$ by treatment (control $=0 \mathrm{~kg} \mathrm{~N} \mathrm{ha}^{-1}$, urea $=179 \mathrm{~kg} \mathrm{~N} \mathrm{ha}^{-1}$, and manure $=$ target application rate of $179 \mathrm{~kg} \mathrm{~N} \mathrm{ha}^{-1}$ ). The number of individual indicators used in each category is delineated in brackets. Error bars represent the standard error of the mean $(n=4)$. Values within soil depth and category marked with different letters are significantly different at $\alpha=0.05$.

(a)

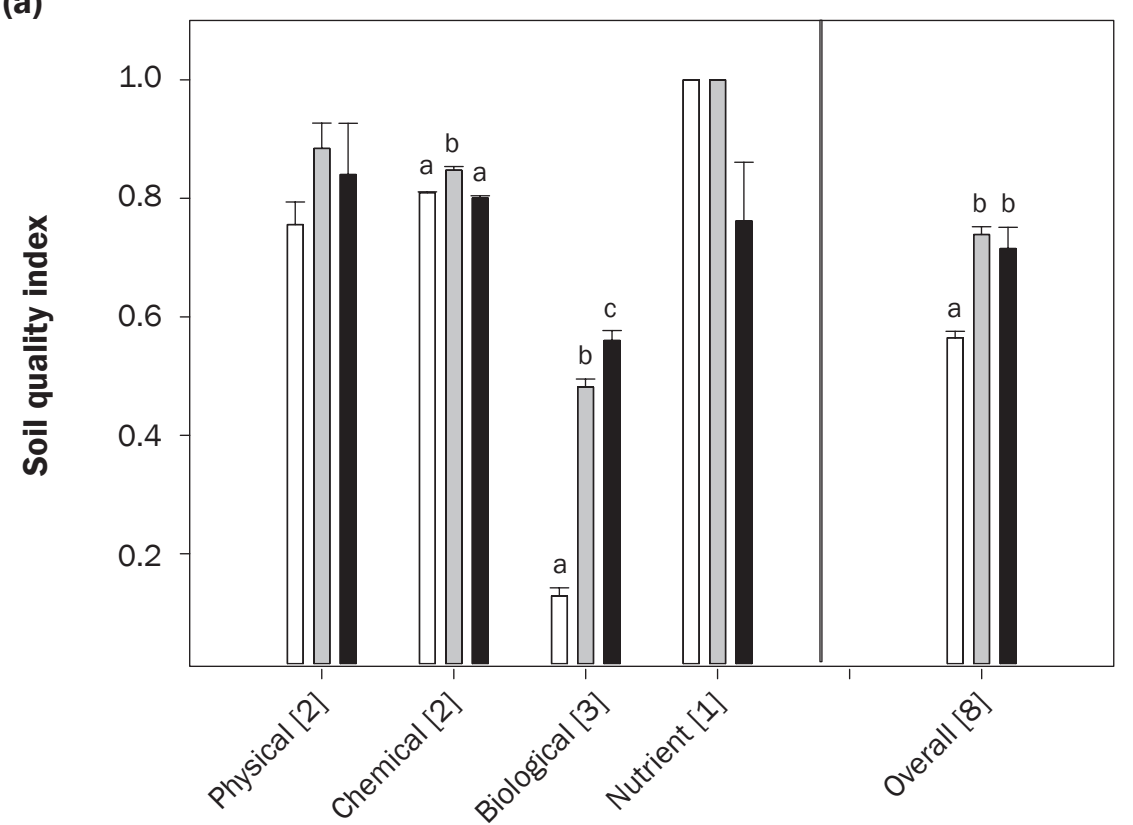

(b)

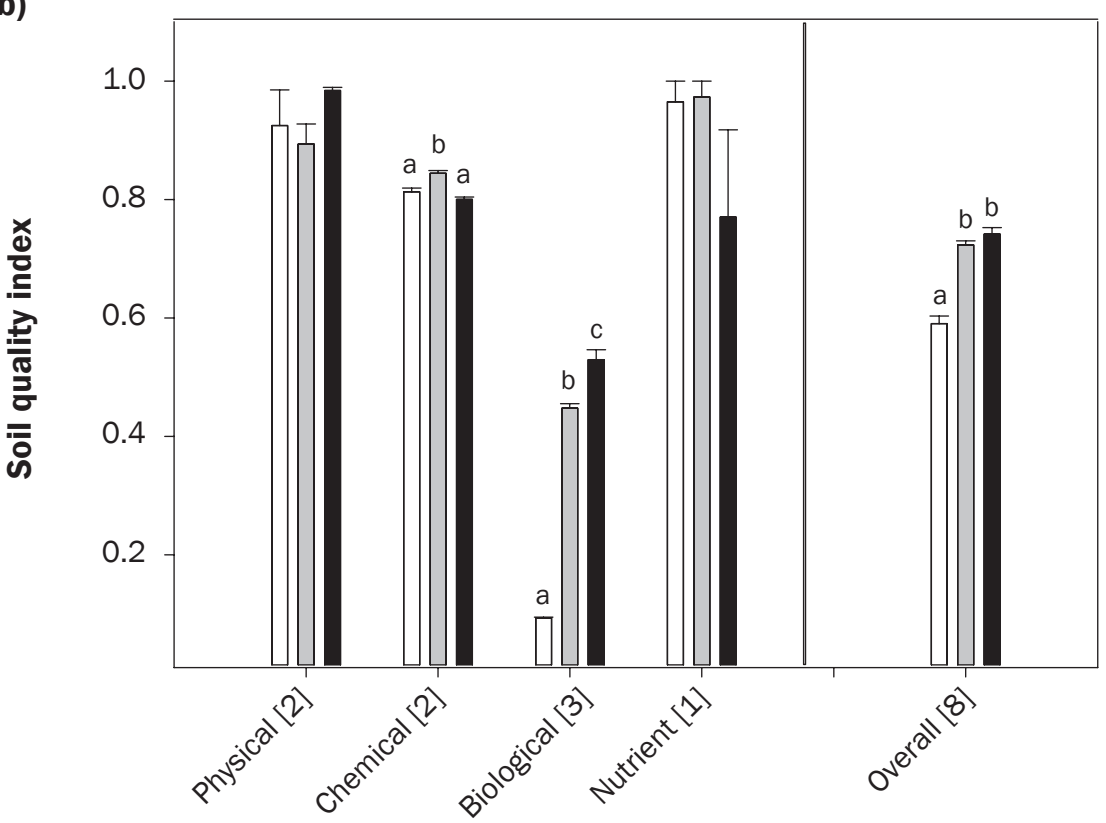

Legend

Control $\square$ Urea $\square$ Manure 
SMAF nutrient SH index penalized the manure treatment due to high STP; however, the index did not account for the fact that although the STP was elevated with manure application, in this system, runoff or wind erosion were minimal, so this was an environmentally safe manure application. The SMAF index should include a separate category for environmental risk, so that cases with high nutrient levels that have low environmental risk (minimal/zero wind erosion and surface runoff) are more accurately represented (Delgado et al. 2008; Sharpley et al. 2003). In addition, the current tool considers only $\mathrm{P}$ and $\mathrm{K}$ in the nutrient $\mathrm{SH}$ index, so the benefits of the manure treatment to soil nutrient status (i.e., greater available $\mathrm{Zn}$, a key nutrient for maize productivity) were not accounted for. Developing scoring function for additional macro- and micronutrients would improve the nutrient SH index and aid in the assessment of how management practices influence the availability of nutrients that can contribute to higher yields and improved crop quality.

Crop Productivity. Productivity was higher in the systems with higher overall $\mathrm{SH}$ (i.e., manure and urea treatments). Stover and cob yields were similar in 2017 and 2018. Averaged across years, the urea and manure treatments had comparable treatment responses, with both fertilizer treatments exceeding the control (figure 6). Grain yields were 10\% higher in the urea and manure treatments in 2017 than in $2018(p<0.05)$. Grain yields did not differ between the urea and manure treatments and averaged $11,450 \mathrm{~kg} \mathrm{ha}^{-1}$ over growing years, nearly $40 \%$ higher than the control, which averaged only $6,740 \mathrm{~kg} \mathrm{ha}^{-1}$. These grain yields were similar to those reported by Halvorson et al. (2016) for the first three years of the study (2012 to 2014).

While the effect of manure versus inorganic $\mathrm{N}$ addition on yields is dependent on factors such as site, management, and manure quality and amount, grain yields in manurebased $\mathrm{N}$ treatments are often equal to or greater than inorganic $\mathrm{N}$ treatment yields (Eghball and Power 1999a; Jokela 1992; Ma et al.1999). We found no differences between inorganic and organic $\mathrm{N}$ sources on stover, cob, or grain yields. These results align with previous work in this system (Halvorson et al. 2016) and indicate that manure is as effective as inorganic $\mathrm{N}$ in supporting high yields in this irrigated, tilled system.

\section{Figure 6}

Average stover, cob, and grain yields in response to inorganic nitrogen (N) (179 kg N ha-1) and manure treatment (estimated available $\mathrm{N}$ of $179 \mathrm{~kg} \mathrm{~N} \mathrm{ha}^{-1}$ ), compared to a control treatment (o $\left.\mathrm{kg} \mathrm{N} \mathrm{ha}{ }^{-1}\right)$. Data are the mean $\pm 1 \mathrm{SE}$ averaged over two growing seasons $(n=8)$. Different lowercase letters within a plant fraction indicate a significant treatment difference at $\alpha=0.05$.

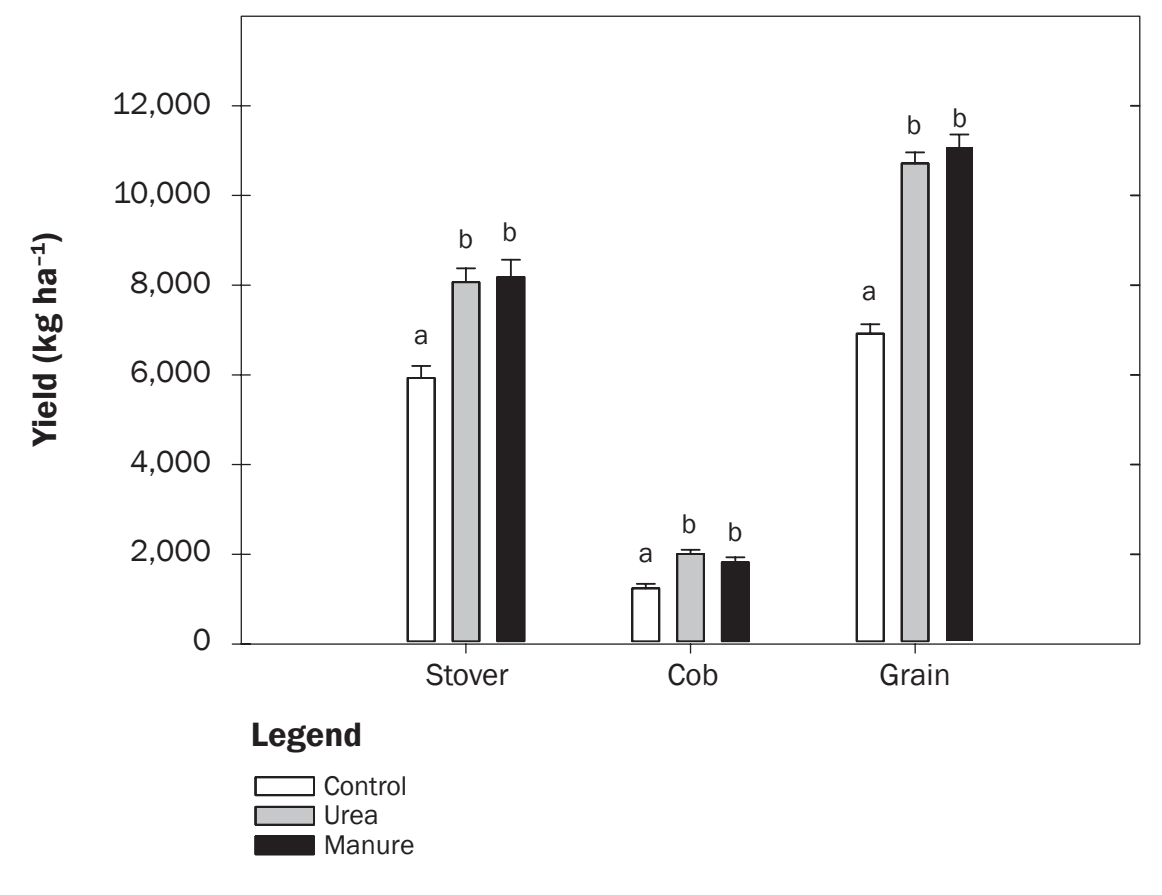

Crop Quality: Nutrient Concentrations and Uptake. Stover [N] was higher in 2017 than in 2018 for all treatments $(p \leq 0.001)$, averaging $8.1 \mathrm{~g} \mathrm{~kg}^{-1}$ in 2017 versus $5.3 \mathrm{~g} \mathrm{~kg}^{-1}$ in 2018. Stover [N] in the urea treatment was higher than the control, whereas stover $[\mathrm{N}]$ in the manure treatment did not differ from the control $(p=0.13)$ (figure 7a). Cob [N] was higher in 2017 than in 2018 (i.e., 4.8 versus $3 \mathrm{~g} \mathrm{~kg}^{-1}$ ), but it was not altered by treatment (figure $7 \mathrm{a}$ ), consistent with the findings of Halvorson and Johnson (2009). Grain [N] was similar in both 2017 and 2018 , but it was $40 \%$ higher in the urea and manure treatments as compared to the control, reaching an upper threshold of $\sim 13 \mathrm{~g}$ $\mathrm{kg}^{-1}$ (figure $7 \mathrm{a}$ ). This maximum grain $[\mathrm{N}]$ is similar to values reported by others for modern maize genotypes (Blesh and Drinkwater 2013; Miner et al. 2018; Woli et al. 2018). The similar stover and grain $[\mathrm{N}]$ between the urea and manure treatment indicate that, despite low spring soil $\mathrm{NO}_{3}-\mathrm{N}$ in the manure treatment, seasonal mineralization rates were sufficient to meet crop $\mathrm{N}$ demands (i.e., figure $2 \mathrm{~d}$ ). The increases in stover and grain [N] in the manure and urea treatments, coupled with higher yields, markedly increased total $\mathrm{N}$ uptake over the control (i.e., by $>100 \mathrm{~kg}$ $\mathrm{N} \mathrm{ha}^{-1}$ ) (table 3).
Stover $[\mathrm{P}]$ was similar in both growing years, but it was nearly twice as high in the manure and control treatments $(>0.90 \mathrm{~g}$ $\left.\mathrm{kg}^{-1}\right)$ as in the urea treatment $\left(0.51 \mathrm{~g} \mathrm{~kg}^{-1}\right)$ (figure $7 b$ ). Stover $[\mathrm{P}]$ in the control and manure treatments was slightly lower than concentrations reported by others (Ciampitti et al. 2013; Mallarino et al. 2011). The lack of increase in stover $[\mathrm{P}]$ in the manure treatment despite high STP levels suggests an upper limit of stover $[\mathrm{P}]$ accumulation, with little or no luxury uptake, which concurs with the results of Mallarino (1996) who found clear upper limits of $\mathrm{P}$ uptake in young plants and leaves "only slightly higher than values needed to produce maximum economic yields." Cob $[\mathrm{P}]$ was similar between growing years but was higher in the manure treatment than in the urea treatment (figure $7 \mathrm{~b}$ ). Grain [P] was $10 \%$ and $25 \%$ lower in 2017 than in 2018 in the manure and urea treatment, respectively, with no interannual differences in the control. Across growing years, grain $[\mathrm{P}]$ in the control and manure treatments averaged 3.32 and $3.28 \mathrm{~g} \mathrm{~kg}^{-1}$, respectively, versus only $2.56 \mathrm{~g} \mathrm{~kg}^{-1}$ in the urea treatment.

The bulk of plant $\mathrm{P}$ accumulates in the grain (Abendroth et al.2011), and hence high grain $[\mathrm{P}]$ in the manure treatment coupled with high yields resulted in higher total $\mathrm{P}$ 


\section{Figure 7}

Stover, cob, and grain macronutrient concentrations by plant compartment averaged over two study years (2017 to 2018) by treatment (control $=0$ $\mathrm{kg}$ nitrogen $[\mathrm{N}] \mathrm{ha}^{-1}$, urea $=179 \mathrm{~kg} \mathrm{~N} \mathrm{ha}^{-1}$, and manure $=$ target application rate of $179 \mathrm{~kg} \mathrm{~N} \mathrm{ha}^{-1}$ ). Error bars represent the standard error of the mean $(n=8)$. Values within plant compartment marked with different letters are significantly different at $\alpha=0.05$.

(a)

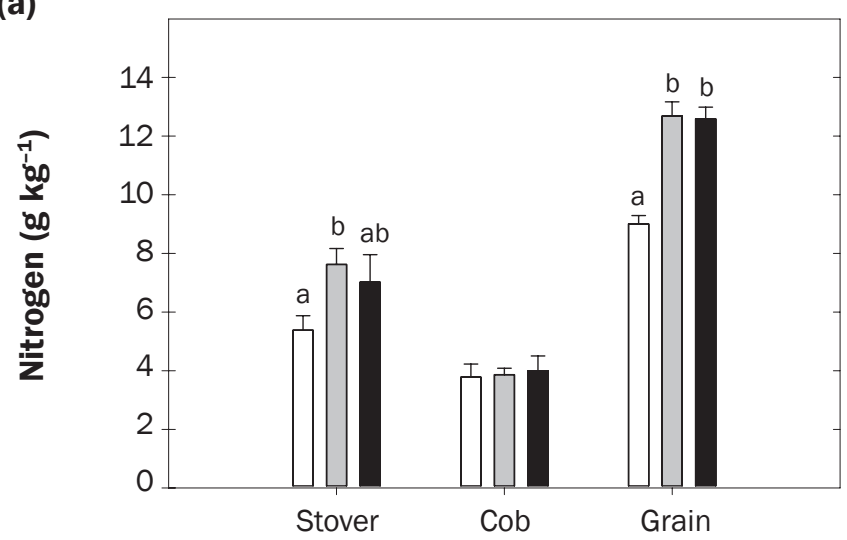

(c)

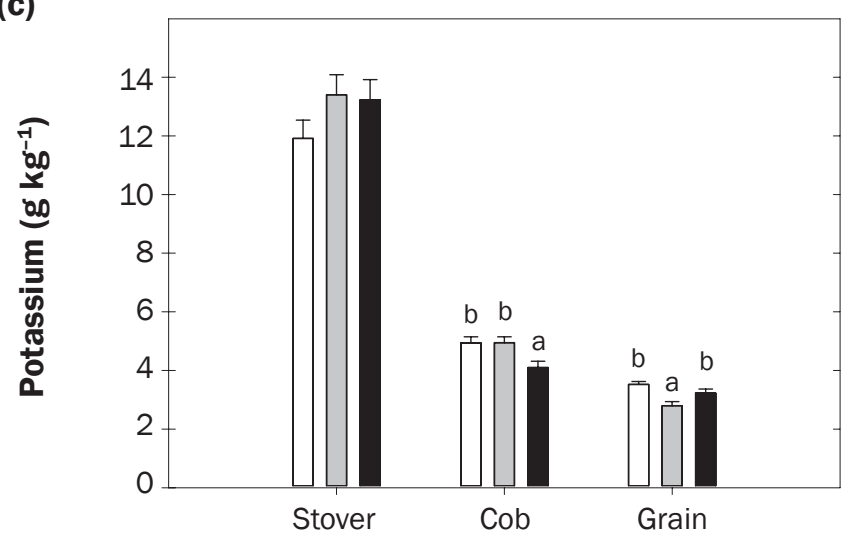

(b)

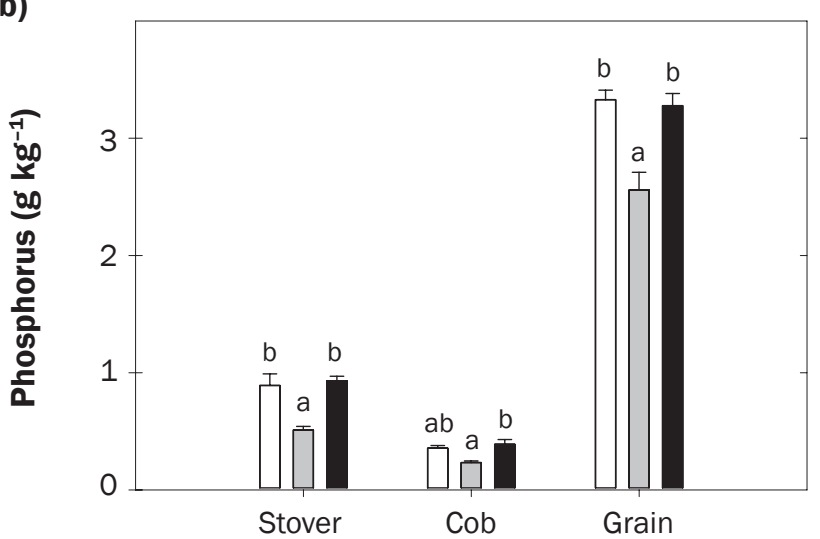

(d)

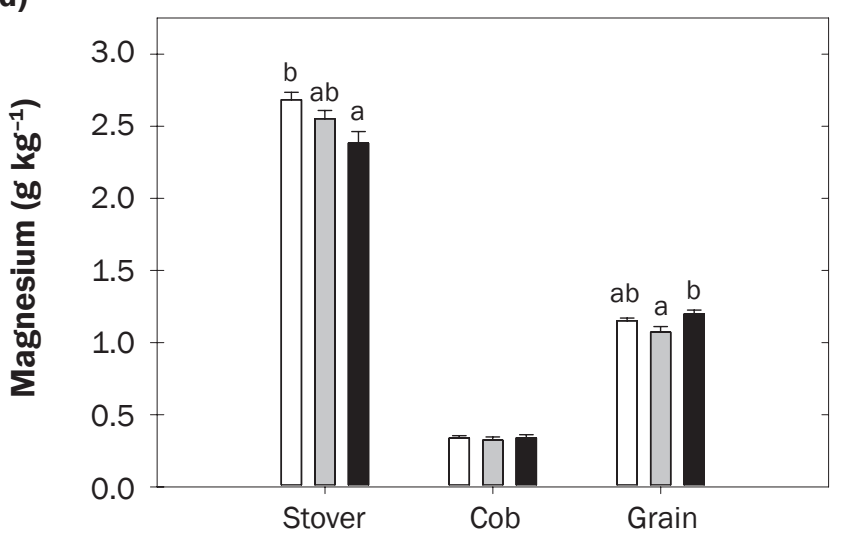

(e)

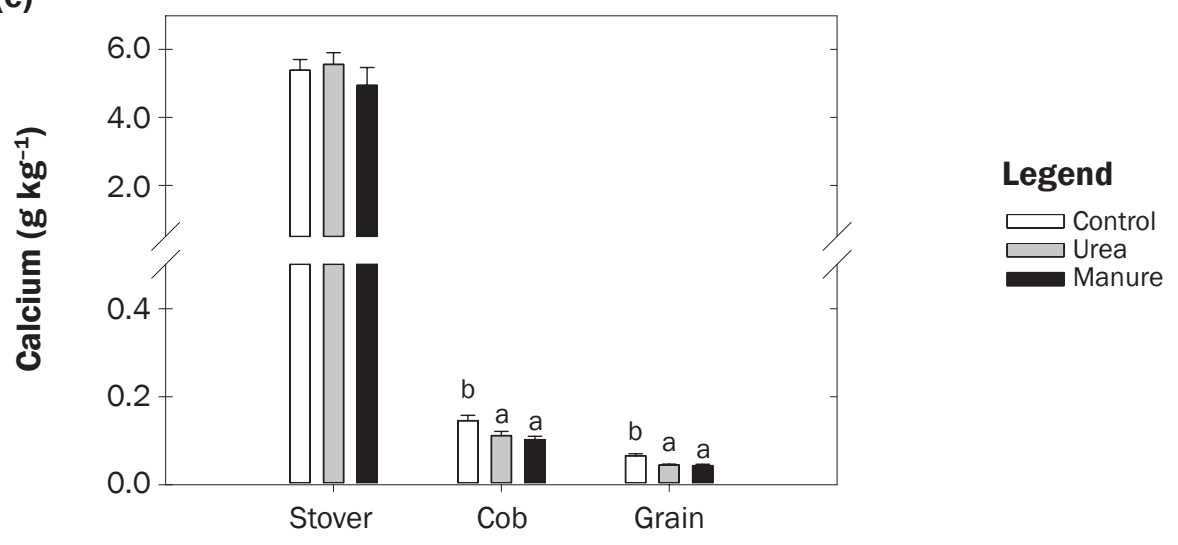

uptake than in the check or urea treatments (table 3). Indeed, we found that $<2 \%$ of total plant $\mathrm{P}$ was in the cob, $12 \%$ to $18 \%$ was in the stalk, and $80 \%$ to $87 \%$ of total plant $\mathrm{P}$ was contained in the grain. Total $\mathrm{P}$ uptake averaged $44.5 \mathrm{~kg} \mathrm{ha}^{-1}$ in the manure treat- ment, versus only 28.6 and $31.9 \mathrm{~kg} \mathrm{ha}^{-1}$ in the check and urea treatments, respectively.

Our results suggest that manure application in this system supports luxury grain $\mathrm{P}$ uptake (i.e., increases in $[\mathrm{P}]$ that do not increase yield). Conversely, the high yields in the urea treatment resulted in a dilution of grain $[\mathrm{P}]$, which is an interesting result as multiple studies have reported that grain $[\mathrm{P}]$ is not readily subject to yield dilutions. For example, Mallarino et al. (2011) found no relationship between grain $[\mathrm{P}]$ and yield across dozens of 


\section{Table 3}

Macronutrient uptake $\left(\mathrm{kg} \mathrm{ha}^{-1}\right)$ for maize (Zea mays L.) by plant fraction for the control treatment, inorganic nitrogen $(\mathrm{N})$ treatment $\left(179 \mathrm{~kg} \mathrm{~N} \mathrm{ha}^{-1}\right)$, and manure treatment (target seasonal $\mathrm{N}$ availability of $179 \mathrm{~kg} \mathrm{~N} \mathrm{ha}^{-1}$ ) over the 2017 and 2018 growing years. Different lowercase letters within nutrient indicate a significant difference between treatments.

\begin{tabular}{lccccc}
\hline Treatment & $\mathbf{N}$ & $\mathbf{P}$ & $\mathbf{K}$ & $\mathbf{M g}$ & $\mathbf{C a}$ \\
\hline Stover & & & & & \\
Control & $32.0 \mathrm{a}$ & $5.2 \mathrm{a}$ & $70.1 \mathrm{a}$ & $15.9 \mathrm{a}$ & 31.9 \\
Inorganic N & $61.9 \mathrm{~b}$ & $4.1 \mathrm{a}$ & $107.3 \mathrm{~b}$ & $20.6 \mathrm{~b}$ & 45.2 \\
Manure & $59.3 \mathrm{~b}$ & $7.6 \mathrm{~b}$ & $108.1 \mathrm{~b}$ & $19.5 \mathrm{~b}$ & 41.1 \\
\hline Cob & & & & & \\
Control & $5.0 \mathrm{a}$ & $0.4 \mathrm{a}$ & $6.2 \mathrm{a}$ & $0.4 \mathrm{a}$ & 0.2 \\
Inorganic N & $7.9 \mathrm{~b}$ & $0.5 \mathrm{ab}$ & $9.9 \mathrm{~b}$ & $0.6 \mathrm{~b}$ & 0.2 \\
Manure & $7.6 \mathrm{~b}$ & $0.7 \mathrm{~b}$ & $7.5 \mathrm{a}$ & $0.6 \mathrm{~b}$ & 0.2 \\
\hline Grain & & & & & \\
Control & $62.5 \mathrm{a}$ & $23.0 \mathrm{a}$ & $24.4 \mathrm{a}$ & $8.0 \mathrm{a}$ & 0.5 \\
Inorganic N & $135.7 \mathrm{~b}$ & $27.3 \mathrm{a}$ & $29.9 \mathrm{~b}$ & $11.5 \mathrm{~b}$ & 0.5 \\
Manure & $139.8 \mathrm{~b}$ & $36.2 \mathrm{~b}$ & $35.5 \mathrm{c}$ & $13.3 \mathrm{c}$ & 0.5 \\
\hline Total uptake & & & & & \\
Control & $99.5 \mathrm{a}$ & $28.6 \mathrm{a}$ & $100.7 \mathrm{a}$ & $24.3 \mathrm{a}$ & 32.5 \\
Inorganic N & $205.4 \mathrm{~b}$ & $31.9 \mathrm{a}$ & $147.1 \mathrm{~b}$ & $32.7 \mathrm{~b}$ & 45.9 \\
Manure & $206.7 \mathrm{~b}$ & $44.5 \mathrm{~b}$ & $151.1 \mathrm{~b}$ & $33.4 \mathrm{~b}$ & 41.7 \\
\hline Notes: P = phosphorus.K= & & & &
\end{tabular}

Notes: $\mathrm{P}=$ phosphorus. $\mathrm{K}=$ potassium. $\mathrm{Mg}=$ magnesium. $\mathrm{Ca}=$ calcium.

years, sites, and treatments, with an average grain $[\mathrm{P}]$ of $3 \mathrm{~g} \mathrm{~kg}^{-1}$. Ciampitti et al. (2013) reported that grain $[\mathrm{P}]$ was stable across multiple $\mathrm{N}$ treatments despite yield variation, averaging $3.6 \mathrm{~g} \mathrm{~kg}^{-1}$. Feil et al. (2005) found no effect of $\mathrm{N}$ fertilization on grain $[\mathrm{P}]$ in two growing years, with an average grain $[\mathrm{P}]$ of $3.23 \mathrm{~g} \mathrm{~kg}^{-1}$. Eghball et al. (2003) reported large variation in grain $[\mathrm{P}]$ between hybrids (i.e., 2.12 to $3.28 \mathrm{~g} \mathrm{~kg}^{-1}$ ) but no impact of $\mathrm{N}$ fertilization or yield on grain $[\mathrm{P}]$. However, STP levels in these studies were likely well above sufficiency levels due to soil $\mathrm{pH}$ levels and $\mathrm{P}$ additions.

In our study, while STP levels in the control and urea treatments were above the levels wherein yield responses are likely, they were likely not high enough to promote luxury P uptake. For example, Barber (1979) examined changes in grain $[\mathrm{P}]$ with five $\mathrm{P}$ rates and found that while yield was maximized at $\sim 11 \mathrm{~kg} \mathrm{P} \mathrm{ha}^{-1}$, grain $[\mathrm{P}]$ continued to increase with additional $\mathrm{P}$ fertilizer additions, indicating luxury $\mathrm{P}$ consumption when STP was high. Mallarino (1996) evaluated grain [P] in response to $\mathrm{P}$ fertilization and reported that while grain $[\mathrm{P}]$ was poorly related to yield, a relationship existed between grain $[\mathrm{P}]$ and surface and subsoil STP in unfertilized plots, with an increasing relative importance of subsoil $\mathrm{P}$ as the growing season advanced. In our study, manure application increased grain
[P] either due to an abundance of STP in the 0 to $15 \mathrm{~cm}$ depth or due to sufficiency in the subsoil (Mallarino 1996; figure 3b). Interestingly, we found that grain $\mathrm{P}$ never rose above $3.42 \mathrm{mg} \mathrm{kg}^{-1}$ despite very high STP values coupled with irrigated conditions that likely maximized soil $\mathrm{P}$ diffusion. Previously published values for expected grain $[\mathrm{P}]$ ranged from 2 to $6 \mathrm{mg} \mathrm{kg}^{-1}$ (Walsh and Beaton 1973). However, our results, coupled with other published results noted above, suggest that the upper limit for grain $[\mathrm{P}]$ is in the range of 3.5 to $4 \mathrm{mg} \mathrm{kg}^{-1}$.

Understanding the conditions that promote luxury P uptake, as well as upper limits for grain $[\mathrm{P}]$, may be important for animal and human nutrition. Luxury $\mathrm{P}$ accumulation is desirable if the goal is to remove $\mathrm{P}$ in harvested products and thereby reduce $\mathrm{P}$ accumulation in soils (Eghball et al. 2003). A large proportion of the maize grown in the United States is used for animal feed. Phosphorus is an essential element in animal nutrition (Kincaid et al. 1981), and while requirements for key minerals such as $\mathrm{P}$ are affected by a various dietary and animal factors, mineral $\mathrm{P}$ supplements are incorporated into diets for many classes of livestock (e.g., swine, poultry, feedlot cattle, and dairy cows) (McDowell 1996).The majority of P in maize grain (i.e., $70 \%$ to $80 \%$ ) occurs as mixed $\mathrm{K}$ and $\mathrm{Mg}$ salts of phytic acid, commonly known as phytate (Lott et al. 2000; Raboy 2001). Although phytate is a poor $\mathrm{P}$ source for monogastrics, there is now widespread use of phytase enzymes in swine and poultry feed, which increase the bioavailability of phytate. Ruminants such as cattle can release this bound $\mathrm{P}$ due to phytase-generating bacteria in the rumen. High stover and grain $[\mathrm{P}]$ hence reduce the amount of supplemental $\mathrm{P}$ that is needed (Kleinman et al. 2018). Maize is also processed for human consumption. While there is some evidence that in humans phytic acid can positively act as an anticancer agent and an antioxidant (Feil 2001), phytate also functions as an "antinutrient," chelating and reducing the bioavailability of minerals such as $\mathrm{Ca}, \mathrm{Fe}$, and $\mathrm{Zn}$, which can pose public health problems in populations at risk of $\mathrm{Fe}$ and $\mathrm{Zn}$ deficiencies (Raboy 2001). In human nutrition, increases in grain $[\mathrm{P}]$ can hence represent either positive or negative shifts in quality, depending on the target population (Lott et al. 2000).

Stover [K] was higher in 2018 than in 2017 (i.e., 14 versus $11.5 \mathrm{~g} \mathrm{~kg}^{-1} ; p \leq 0.05$ ). Stover $[\mathrm{K}]$ was not influenced by treatment, despite the higher soil $\mathrm{K}$ in the manure treatment (figure 7c). Stover [K] averaged 12.9 $\mathrm{g} \mathrm{kg}^{-1}$ over treatments and years, similar to the value reported by Mallarino et al. (2011). Cob [K] was slightly lower in the manure treatment $\left(4.1 \mathrm{~g} \mathrm{~kg}^{-1}\right)$ than in the control and urea treatments $\left(4.9 \mathrm{~g} \mathrm{~kg}^{-1}\right)$. Grain $[\mathrm{K}]$ was lower in 2018 than in 2017 (i.e., 3.4 versus $2.9 \mathrm{~g} \mathrm{~kg}^{-1}$, respectively; $\left.p \leq 0.05\right)$. Grain $[\mathrm{K}]$ averaged $2.8 \mathrm{~g} \mathrm{~kg}^{-1}$ in the urea treatment versus 3.2 and $3.5 \mathrm{~g} \mathrm{~kg}^{-1}$ in the manure and check treatments $(p<0.05)$. Grain $[\mathrm{K}]$ typically ranges from 2 to $5 \mathrm{~g} \mathrm{~kg}^{-1}$ (Bruns and Ebelhar 2006; Ciampitti et al. 2013; Feil et al. 2005). While other studies have found no dilution of grain $[\mathrm{K}]$ with yield (Ciampitti et al. 2013; Mallarino et al. 2011), our results suggest both a dilution of grain $[\mathrm{K}]$ with urea fertilization as well as a synergistic effect of manure on grain $[\mathrm{K}]$ (i.e., $15 \%$ higher grain $[\mathrm{K}]$ despite no yield differences). Although we did not measure phytate directly, phytate is a mixed cation salt, and the negatively charged sites of phytic acid typically bind with K and Mg (Marschner 1995). Hence, increases in grain $[\mathrm{P}]$ with manure would be expected to synergistically increase grain [K] and $[\mathrm{Mg}]$. Total $\mathrm{K}$ uptake ranged from 100.7 $\mathrm{kg} \mathrm{ha}^{-1}$ in the control treatment to $151.1 \mathrm{~kg}$ $\mathrm{ha}^{-1}$ in the manure treatment (table 3 ). 


\section{Figure 8}

Stover, cob, and grain copper, iron, and manganese concentrations by plant compartment, averaged over two study years (2017 and 2018) by treatment (control $=0 \mathrm{~kg}$ nitrogen $[\mathrm{N}] \mathrm{ha}^{-1}$, urea $=179 \mathrm{~kg} \mathrm{~N} \mathrm{ha}^{-1}$, and manure $=$ target application rate of $179 \mathrm{~kg} \mathrm{~N} \mathrm{ha}^{-1}$ ). Error bars represent the standard error of the mean $(n=8)$. Values within plant compartment marked with different letters are significantly different at $\alpha=0.05$.

(a)

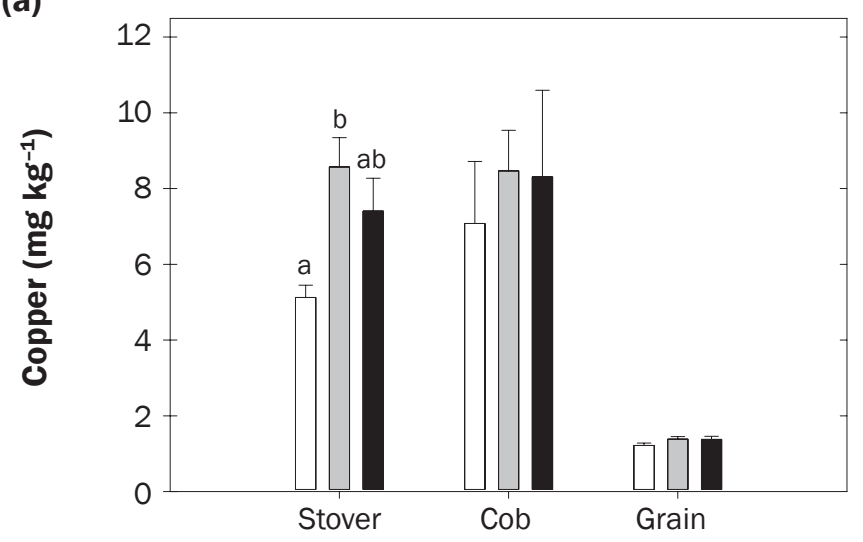

(b)

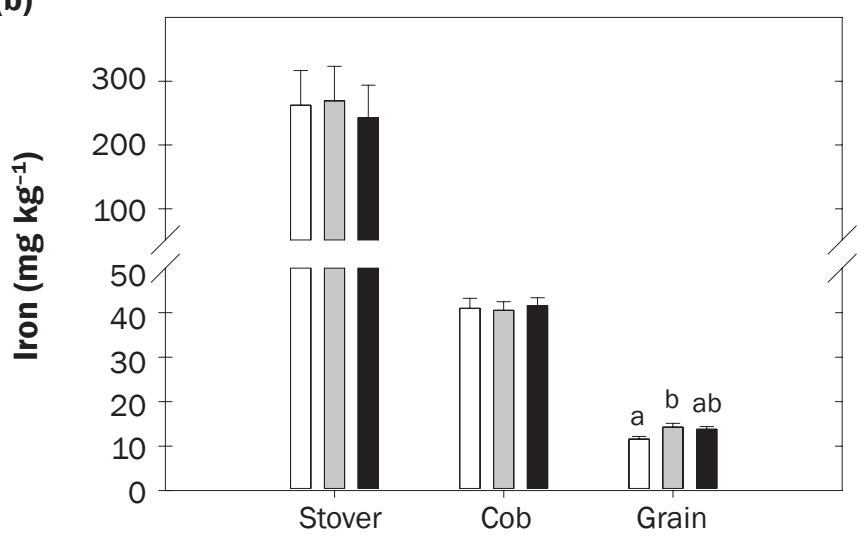

(c)

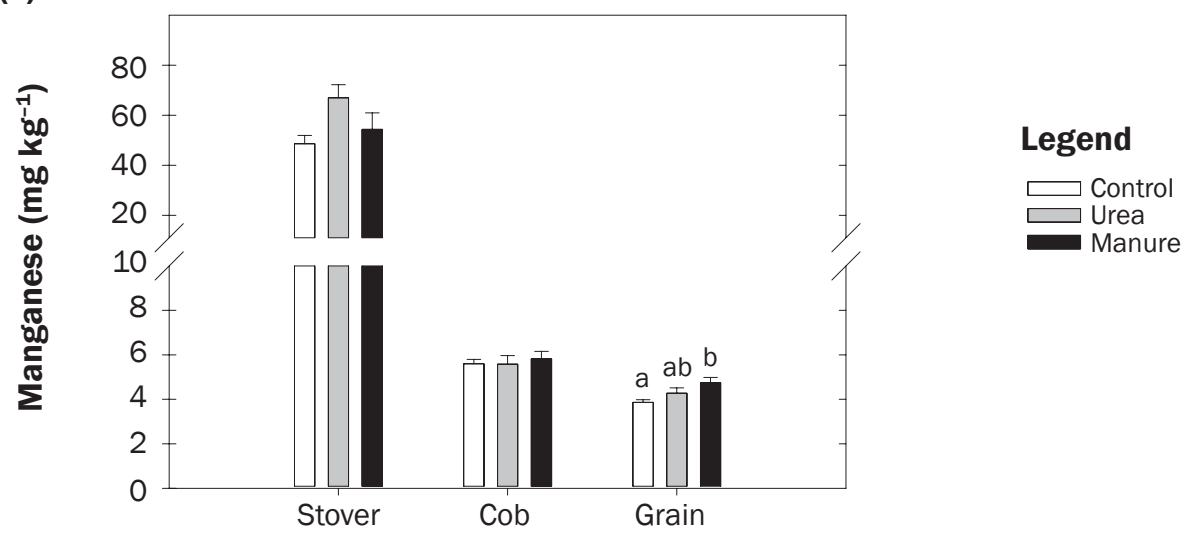

Stover $[\mathrm{Mg}]$ did not vary between growing years and ranged from 2.38 to $2.68 \mathrm{~g}$ $\mathrm{kg}^{-1}$ (figure $7 \mathrm{~d}$ ). These stover $\mathrm{Mg}$ concentrations are 0.5 to $1 \mathrm{~g} \mathrm{~kg}^{-1}$ higher than those reported by others (Bruns and Ebelhar 2006; Ciampitti and Vyn 2013; Feil et al. 2005). Stover $[\mathrm{Mg}]$ was lower in the manure treatment than in the control $(p=0.02)$. Cob $[\mathrm{Mg}]$ did not vary between treatments and averaged only $0.32 \mathrm{~g} \mathrm{~kg}^{-1}$. Grain $[\mathrm{Mg}]$ ranged from 1.07 to $1.2 \mathrm{~g} \mathrm{~kg}^{-1}$ and was $10 \%$ lower in the urea treatment than in the manure treatment. Feil et al. (2005) reported similar grain $[\mathrm{Mg}]$ (i.e., $1.12 \mathrm{~g} \mathrm{~kg}^{-1}$ ), but found no change in grain $[\mathrm{Mg}]$ with $\mathrm{N}$ fertility or yield, whereas Ciampitti and Vyn (2013) noted grain $[\mathrm{Mg}]$ ranging from 1.35 to 1.71 $\mathrm{g} \mathrm{kg}^{-1}$ and found increases in grain $[\mathrm{Mg}]$ in response to $\mathrm{N}$. We found that grain $[\mathrm{Mg}]$ was highest in the manure treatment, likely due to the same mechanisms posited for increases in grain $[\mathrm{K}]$. Total uptake ranged from 24.3 to $33.4 \mathrm{~kg} \mathrm{ha}^{-1}$ and was highest in the urea and manure treatments (table 3 ).

Stover [Ca] was 25\% higher in 2017 than in 2018 (i.e., $5.85 \mathrm{~g} \mathrm{~kg}^{-1}$ versus 4.74 $\left.\mathrm{g} \mathrm{kg}^{-1} ; p=0.04\right)$ but was not impacted by treatment (figure 7e). Some studies have reported increases in stover [Ca] with $\mathrm{N}$ fertilization (Ciampitti and Vyn 2013), but we did not observe this, likely due to high soil $\mathrm{Ca}$ concentrations. The stover [Ca] we measured was approximately twice as high as those reported by others (Bruns and Ebelhar 2006; Ciampitti and Vyn 2013). High levels of $\mathrm{Ca}$ in the external soil solution typically increase the $\mathrm{Ca}$ concentrations in plant leaves, whereas these effects are not necessarily seen in low-transpiring organs supplied via the phloem (i.e., grain) due to restriction of $\mathrm{Ca}$ transport in the phloem stream (Marschner 1995). Indeed, cob [Ca] was
$<3 \%$ of stover [Ca], averaging $0.10 \mathrm{~g} \mathrm{~kg}^{-1}$ in the manure and urea treatment versus $0.14 \mathrm{~g}$ $\mathrm{kg}^{-1}$ in the control. Grain [Ca] was $<1 \%$ of stalk [Ca], averaging $0.04 \mathrm{~g} \mathrm{~kg}^{-1}$ in the urea and manure treatments versus $0.06 \mathrm{~g} \mathrm{~kg}^{-1}$ in the control. A dilution in grain [Ca] with $\mathrm{N}$ fertility was also reported by Feil et al. (2005), whereas other studies have not found this effect (Ciampitti andVyn 2013). Total uptake ranged from 32.5 to $45.9 \mathrm{~kg} \mathrm{ha}^{-1}$ and did not differ between treatments (table 3 ).

Stover [Cu] ranged from 5.1 to $8.6 \mathrm{mg}$ $\mathrm{kg}^{-1}$ (figure 8a), similar to the levels reported by others (Berenguer et al. 2008; Bruns and Ebelhar 2006; Losak et al. 2011; Miner et al. 2018). Stover $[\mathrm{Cu}]$ was higher in the urea treatment than in the control (figure 8a). However, despite the increase in $\mathrm{Cu}_{\text {avail }}$ with manure, stover $[\mathrm{Cu}]$ in the manure treatment did not differ from the control or urea treatment. Other studies have also reported no 
differences in stover $[\mathrm{Cu}]$ between manure and inorganic $\mathrm{N}$ treatments (Berenguer et al. 2008; McIntosh and Varney 1972). Interestingly, multiple studies have found that when soil $\mathrm{Cu}$ concentrations are elevated, maize plants can accumulate very high levels of $\mathrm{Cu}$ in the roots (i.e., 60 to $600 \mathrm{mg} \mathrm{kg}^{-1}$ ) and yet tightly restrict translocation to shoots to keep aerial and grain concentrations low (Brun et al. 2001; Jarausch-Wehrheim et al. 1996; Mantovi et al. 2003). Translocation of $\mathrm{Cu}$ from the roots to the aerial organs is thought to be controlled by $\mathrm{N}$ metabolism, with $\mathrm{Cu}$ moving in the xylem complexed with organic-N ligands or chelated to amino acids (Marschner 1995). Hence, providing soil $\mathrm{Cu}$ levels are not deficient, additional increases in soil $\mathrm{Cu}$ due to manure application should not increase stover $[\mathrm{Cu}]$; rather stover $[\mathrm{Cu}]$ should correlate with $\mathrm{N}$ uptake and movement. Indeed, the correlation between stover $[\mathrm{Cu}]$ and $[\mathrm{N}]$ was $r>0.90$ in both growing years. These results are consistent with other studies that have found a synergistic relationship between stover [N] and [Cu] (Bruns and Ebelhar 2006; Ciampitti and Vyn 2013; Miner et al. 2018).

The higher stover $[\mathrm{Cu}]$ in the manure and urea treatments did not result in higher cob or grain $[\mathrm{Cu}]$ than in the control (figure $8 \mathrm{a}$ ). Grain $[\mathrm{Cu}]$ measured $<1.4 \mathrm{mg} \mathrm{kg}^{-1}$. While $\mathrm{Cu}$ mobility from the vegetative tissues to the grain via the phloem is not well understood (Grusak et al. 1999), we found no evidence of increased $\mathrm{Cu}$ remobilization with higher source $\mathrm{Cu}$ in maize, nor did grain $[\mathrm{Cu}]$ parallel increases in grain $[\mathrm{N}]$. The percentage of $\mathrm{Cu}$ in the grain was $<18 \%$ of total plant $\mathrm{Cu}$ in all three treatments. Our results agree with other studies that have reported increases in stover $[\mathrm{Cu}]$ with increased $\mathrm{N}$ fertility, with no corresponding changes in grain $[\mathrm{Cu}$ (Bruns and Ebelhar 2006; Miner et al. 2018). Maximum total $\mathrm{Cu}$ uptake was $\approx 0.1 \mathrm{~kg} \mathrm{ha}^{-1}$ (table 4).

Stover [Fe] was not influenced by treatment (figure $8 \mathrm{~b}$ ) but differed between growing years $(p=<0.001)$. Stover [Fe] was $225 \%$ higher in 2017 than in 2018, averaging 394.5 $\mathrm{mg} \mathrm{kg}{ }^{-1}$ in 2017 versus only $121.7 \mathrm{mg} \mathrm{kg}^{-1}$ in 2018. While the differences in genotypes between growing years make it impossible to attribute differences entirely to growing year, Miner et al. (2018) also reported an 80\% difference in stover [Fe] between two growing years where the same maize hybrid was grown, suggesting that factors such as soil

\section{Table 4}

Micronutrient uptake ( $\mathrm{g} \mathrm{ha}^{-1}$ ) for maize (Zea mays L.) by plant fraction for the control treatment (o kg N ha-1), inorganic nitrogen $(\mathrm{N})$ treatment $\left(179 \mathrm{~kg} \mathrm{~N} \mathrm{ha}^{-1}\right.$ ), and manure treatment (target seasonal $\mathrm{N}$ availability of $179 \mathrm{~kg} \mathrm{~N} \mathrm{ha}^{-1}$ ) over the 2017 and 2018 growing years. Different lowercase letters within nutrient indicate a significant difference between treatments.

\begin{tabular}{lcccc}
\hline Treatment & $\mathbf{C u}$ & $\mathbf{F e}$ & $\mathbf{M n}$ & $\mathbf{Z n}$ \\
\hline Stover & & & & \\
Control & $30.1 \mathrm{a}$ & $1,551.0$ & $288.7 \mathrm{a}$ & $219.9 \mathrm{a}$ \\
Inorganic N & $61.7 \mathrm{~b}$ & $2,211.6$ & $546.9 \mathrm{~b}$ & $312.2 \mathrm{~b}$ \\
Manure & $69.4 \mathrm{~b}$ & $2,045.0$ & $455.4 \mathrm{ab}$ & $306.9 \mathrm{~b}$ \\
\hline Cob & & & & \\
Control & 9.7 & $50.3 \mathrm{a}$ & $7.0 \mathrm{a}$ & 33.9 \\
Inorganic N & 15.3 & $80.7 \mathrm{~b}$ & $11.0 \mathrm{~b}$ & 28.8 \\
Manure & 17.8 & $75.0 \mathrm{~b}$ & $10.6 \mathrm{~b}$ & 35.3 \\
\hline Grain & & & & \\
Control & $8.4 \mathrm{a}$ & $80.1 \mathrm{a}$ & $26.8 \mathrm{a}$ & $143.1 \mathrm{a}$ \\
Inorganic N & $15.3 \mathrm{~b}$ & $152.4 \mathrm{~b}$ & $29.9 \mathrm{~b}$ & $192.5 \mathrm{~b}$ \\
Manure & $14.9 \mathrm{~b}$ & $153.2 \mathrm{~b}$ & $35.5 \mathrm{c}$ & $209.7 \mathrm{~b}$ \\
\hline Total Uptake & & & & \\
Control & $48.2 \mathrm{a}$ & $1,681.3 \mathrm{a}$ & $322.4 \mathrm{a}$ & $396.9 \mathrm{a}$ \\
Inorganic N & $102.1 \mathrm{~b}$ & $2,444.6 \mathrm{a}$ & $603.5 \mathrm{~b}$ & $533.5 \mathrm{~b}$ \\
Manure & $92.4 \mathrm{~b}$ & $2,273.2 \mathrm{ab}$ & $518.8 \mathrm{ab}$ & $551.9 \mathrm{~b}$ \\
\hline
\end{tabular}

Notes: $\mathrm{Cu}=$ copper. $\mathrm{Fe}=$ iron. $\mathrm{Mn}=$ manganese. $\mathrm{Zn}=$ zinc.

and growth conditions (i.e., temperature and moisture) may contribute to large interannual differences in stover [Fe] (Fageria et al. 2002). Cob [Fe] was lower in 2017 than in 2018 (i.e., $38.4 \pm 3.2 \mathrm{mg} \mathrm{kg}^{-1}$ versus $43.6 \pm$ $\left.6 \mathrm{mg} \mathrm{kg}^{-1} ; p=0.048\right)$ but was not influenced by treatment. Despite the higher stover [Fe] in 2017, grain [Fe] was lower in 2017 than in 2018 (i.e., $12.6 \mathrm{mg} \mathrm{kg}^{-1}$ versus $13.9 \mathrm{mg}$ $\left.\mathrm{kg}^{-1} ; p=0.03\right)$. Grain [Fe] was influenced by treatment, with higher grain $[\mathrm{Fe}]$ in the urea versus the check treatment $(p=0.04)$, whereas differences between the check and manure treatments were not significant $(p=$ $0.09)$. There was a strong correlation between grain $[\mathrm{Fe}]$ and grain $[\mathrm{N}]$ in both growing years $(r=0.70$ and $r=0.83)$, which concurs with the grain $[\mathrm{N}]-[\mathrm{Fe}]$ synergism reported by Miner et al. (2018). Interestingly, while the processes of $\mathrm{N}$ remobilization to the grain are largely understood (Hay and Porter 2006), comparatively little is known about the processes of Fe movement or remobilization to the grain (Grusak and DellaPenna 1999). This synergism could perhaps be due to factors that are improved with $\mathrm{N}$ nutrition (i.e., root proliferation and/or longevity, canopy photosynthetic capacity and longevity), simultaneously supporting $\mathrm{Fe}$ uptake and movement (Marschner 1995).

These results imply that grain [Fe] is not controlled solely by $[\mathrm{Fe}]$ in vegetative source tissues, and stover [Fe] may not reflect $\mathrm{Fe}$ available for transport to the grain. Other studies have demonstrated that total leaf Fe content is of limited value as an indicator of Fe nutritional status - only a fraction of $\mathrm{Fe}$ is thought to be physiologically active, with a large amount of Fe accumulated in unavailable forms (Abadía 1992; Marschner 1995). In addition, phloem loading and transport of Fe from the stover to the grain is limited by the need for a specific chelator (Grusak et al. 1999), which may also limit final grain [Fe]. Interestingly, Fe partitioning and movement between vegetative and reproductive organs varies widely between crop species. For example, Fe deposition to the seed in pea (Pisum sativum L.) was found to represent $75 \%$ of total shoot Fe, whereas in rice (Oryza sativa L.) only $4 \%$ of shoot Fe was partitioned to the grain (Grusak and DellaPenna 1999). In 2017 , we found that only $3 \%$ to $5 \%$ of stover Fe was partitioned to the grain in 2017, versus $12 \%$ to $17 \%$ in 2018 . Despite high stover Fe contents, only a small amount of Fe was remobilized to the grain in maize. Total Fe uptake ranged from 1,681 to 2,445 $\mathrm{g} \mathrm{ha}^{-1}$ (table 3).

Stover [Mn] was 25\% higher in 2017 than in $2018(p=0.04)$, whereas cob and grain $[\mathrm{Mn}]$ did not differ between growing years. Averaged over year, stover [Mn] ranged from 48.6 to $67 \mathrm{mg} \mathrm{kg}^{-1}$ between treatments 
(figure 8c), well above published sufficiency levels of 10 to $25 \mathrm{mg} \mathrm{kg}^{-1}$ (Mengel and Kirkby 1982) and similar to concentrations reported elsewhere (Ciampitti andVyn 2013; Miner et al. 2018). Higher stover [Mn] in 2017 likely reflects seasonal differences in environmental variables that influence $\mathrm{Mn}$ and water availability to the roots and transpiration, as $\mathrm{Mn}$ is easily mobilized from the root to the shoot in the xylem (Kochian 1991). Treatment impacts on plant $[\mathrm{Mn}]$ were only evident in the grain, where grain $[\mathrm{Mn}]$ in the manure treatment averaged $4.8 \mathrm{mg} \mathrm{kg}^{-1}, 23 \%$ higher than the control $\left(3.9 \mathrm{mg} \mathrm{kg}^{-1}\right)$ but not different from the urea treatment. Maximum total $\mathrm{Mn}$ annual uptake was $\sim 0.6 \mathrm{~kg} \mathrm{Mn} \mathrm{ha}{ }^{-1}$ (table 3).

Several studies have reported no changes in grain $[\mathrm{Mn}]$ with higher $\mathrm{N}$ fertility (Brun et al. 2001; Losak et al. 2011; Miner et al. 2018), while others have found increased grain $[\mathrm{Mn}]$ with $\mathrm{N}$ fertilization (Ciampitti and Vyn 2013; Feil et al. 2005). We found a detectable synergistic treatment impact of manure on grain [Mn].

Despite the increase in $\mathrm{Zn}_{\text {avail }}$ with manure application, there were no treatment differences in stover $[\mathrm{Zn}]$ in either growing year (figure 9). Stover [Zn] averaged $37.8 \mathrm{mg} \mathrm{kg}^{-1}$, well within the whole plant $[\mathrm{Zn}]$ sufficiency range of 20 to $50 \mathrm{mg} \mathrm{kg}^{-1}$ (Mengel and Kirkby 1982) and similar to other published values (Bruns and Ebelhar 2006; Ciampitti and Vyn 2013; Miner et al. 2018). The interactions between $\mathrm{Zn}$ and $\mathrm{N}$ nutrition in the published literature are not consistent; some studies have found declines in stover [Zn] with increasing $\mathrm{N}$ fertility (Ciampitti and Vyn 2013; Miner et al. 2018), while others have reported no changes in stover [ $\mathrm{Zn}$ ] with N (Bruns and Ebelhar 2006; Losak et al. 2011). Cob [Zn] was impacted by treatment $(p<0.05)$ but not growing year.

There was an interaction between year and treatment on grain $[\mathrm{Zn}](p=0.03)$ (figure 9). Grain [Zn] ranged from 17.4 to $23.2 \mathrm{mg}$ $\mathrm{kg}^{-1}$ between treatments and growing years, similar to other published values (Berenguer et al. 2008; Bruns and Ebelhar 2006; Losak et al. 2011; Miner et al. 2018). Grain [Zn] levels were approximately 2 to $5 \mathrm{mg} \mathrm{kg}^{-1}$ higher in 2017 than in 2018 in the control and manure treatments, whereas grain $[\mathrm{Zn}]$ did not vary between years in the urea treatment. In 2017, grain $[\mathrm{Zn}]$ declined in both the urea and manure treatments compared to the control, whereas in 2018 there were no treatment

\section{Figure 9}

Stover, cob, and grain zinc concentrations by plant compartment for (a) 2017 and (b) 2018 by treatment (control $=0 \mathrm{~kg}$ nitrogen $[\mathrm{N}] \mathrm{ha}^{-1}$, urea $=179 \mathrm{~kg} \mathrm{~N} \mathrm{ha}^{-1}$, and manure $=$ target application rate of $\left.179 \mathrm{~kg} \mathrm{~N} \mathrm{ha}^{-1}\right)$. Error bars represent the standard error of the mean $(n=4)$. Values within plant compartment marked with different letters are significantly different at $\alpha=0.05$.

(a)

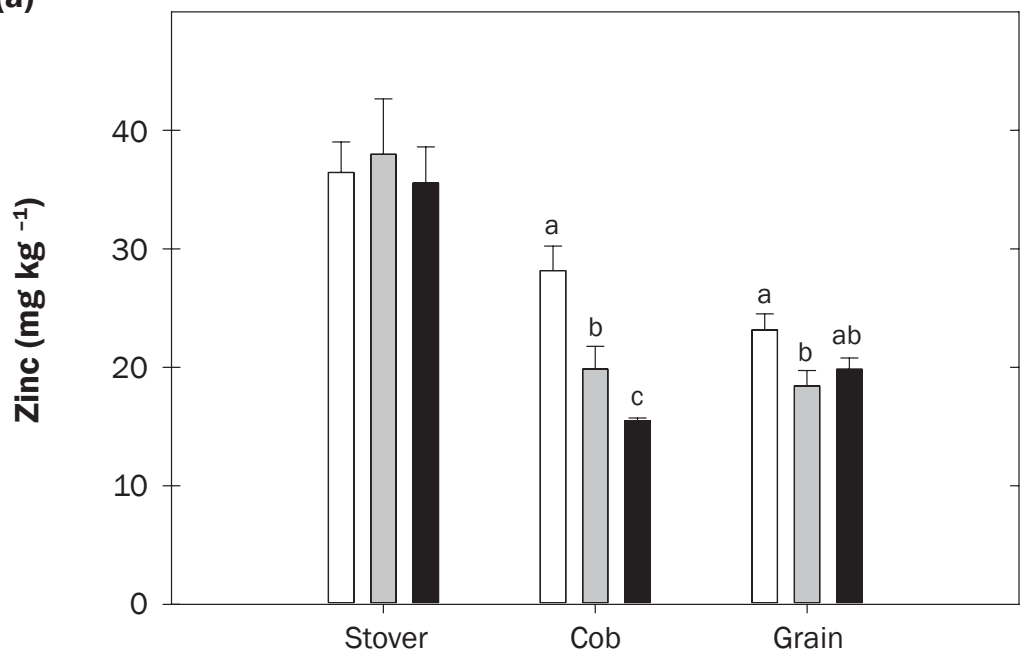

(b)

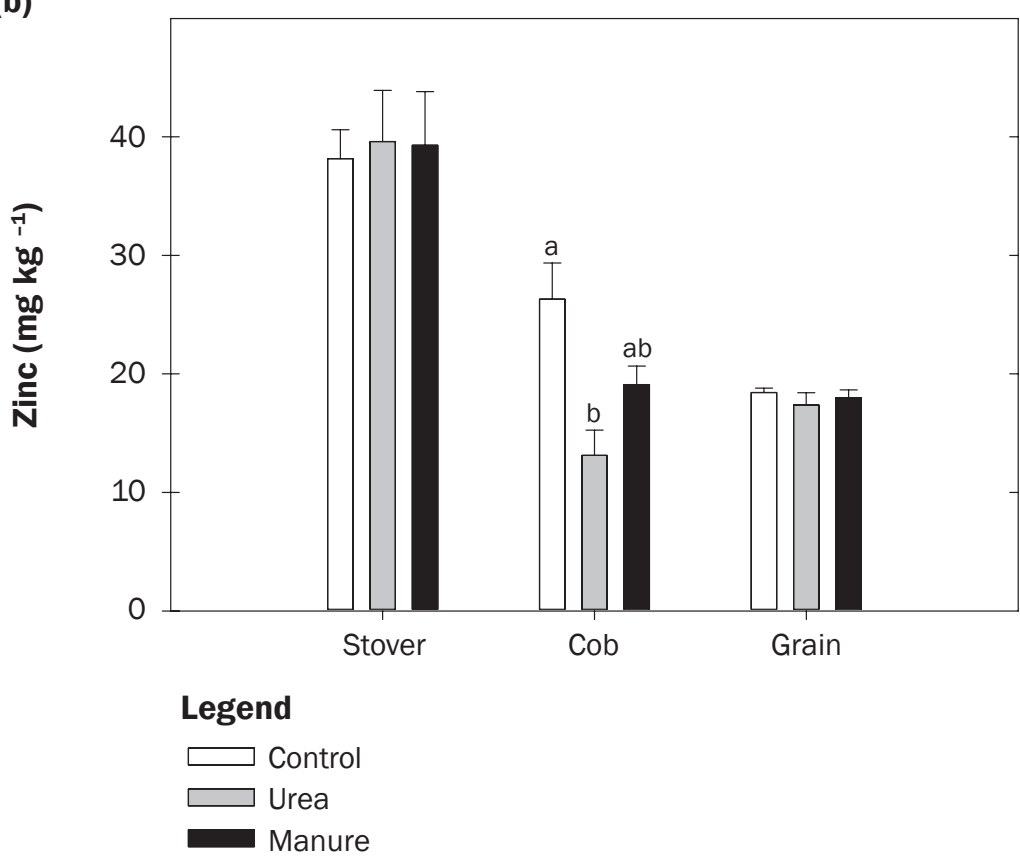

differences in grain [Zn]. These interannual differences in $N$ treatment impacts on grain [Zn] suggest either curtailment of $\mathrm{Zn}$ uptake and/or remobilization during the grain filling period in 2017 , or prolonged remobilization of carbohydrates from leaves and stalk to the grain that was not matched by $\mathrm{Zn}$ uptake and/or remobilization. Reported impacts of $\mathrm{N}$ on grain [Zn] are disparate, with multiple studies reporting no change in grain [Zn] with $\mathrm{N}$ fertility (Bruns and Ebelhar 2006; Losak et al. 2011; Riedell et al. 2009), whereas others have found reductions in grain $[\mathrm{Zn}]$ with increasing $\mathrm{N}$ (Bruns and Ebelhar 2006; Feil et al. 2005; Li et al. 2007; Miner et al. 2018; Riedell et al. 2009). Zinc concentrations in multiple cereal grains have been shown to increase in response to $\mathrm{Zn}$ additions, even when yield responses are not evident (Marschner 1995; Rengel et al. 
1999), which suggests that the variability in observed responses is likely due to differences in available soil $\mathrm{Zn}$ between studies. Total Zn uptake ranged from 0.40 to $0.53 \mathrm{~kg}$ $\mathrm{ha}^{-1}$ between treatments (table 3 ).

\section{Summary and Conclusions}

We examined the connections between $\mathrm{SH}$, crop productivity, and crop quality in a continuous maize system with treatments varying in input type and amount. The overall SH index was higher in the manure and urea treatments than in the control, but no differences in this index between the organic and inorganic $\mathrm{N}$ sources were found despite the large exogenous sources of $\mathrm{C}, \mathrm{N}$, and nutrients applied via manure. The biological $\mathrm{SH}$ index was higher for the manure-treated soils than the urea and control treatments, reflecting the increases in SOC and enzyme activities with manure addition. The SMAF nutrient index penalized the manure treatment due to high STP; however, in this study, runoff or wind erosion were minimal, so this should be considered an environmentally safe manure application, even if high STP were measured. In addition, the current SMAF tool considers only $\mathrm{P}$ and $\mathrm{K}$ in terms of soil nutrients - the nutrient benefits of manure application (i.e., higher TSN, increases in available soil micronutrients) were not accounted for, suggesting that the SMAF nutrient SH index should be modified to account for the impacts of management practices on nutrient availability.

Both the inorganic and organic $\mathrm{N}$ amendments improved $\mathrm{SH}$ and crop productivity over the control treatment. Despite widely differing nutrient inputs and soil fertility levels, there were no yield differences between urea and manure treatments, indicating that manure was as effective as inorganic $\mathrm{N}$ in supporting yields in this system. However, there were notable differences in crop quality between treatments. Stover [N] was 30\% to $50 \%$ higher in the urea and manure treatments than in the control, and stover $[\mathrm{P}]$ was $80 \%$ higher in the manure treatment than in the urea treatment. These differences in stover composition will impact the quality of silage in silage production systems. Grain $[\mathrm{N}]$ was $40 \%$ higher in the urea and manure treatments than in the control. Grain P, K, and $\mathrm{Mg}$, important elements in livestock nutrition, were also higher in the manure treatment than in the urea treatment, indicating improvements in crop nutritional quality and reductions in supplement costs for producers. In addition, the $\mathrm{Zn}$ dilution effect observed in the urea treatment was slightly mitigated in the manure treatment, likely due to increases in available soil $\mathrm{Zn}$. Hence, although the overall SH was the same between the urea and manure treatments, there were additional increases in crop quality in the manure treatment that were not captured by the $\mathrm{SH}$ index. While this work examines the interrelationships between management, productivity, and crop quality for maize, understanding these relationships for other staple crops is a critical component of combating food system nutrient deficiencies at the field level. Our results suggest that management practices that support soil health and nutrient availability also support the productivity and nutritional quality of maize, which could have positive impacts on animal and human nutrition.

\section{References}

Abadía, J. 1992. Leaf responses to Fe deficiency: A review. Journal of Plant Nutrition 15(10):1699-1713.

Abendroth, L.J., R.W. Elmore, M.J. Boyer, and S.K. Marlay. 2011. Corn Growth and Development. PMR 1009. Ames, IA: Iowa State University Extension.

Acosta-Martinez, V., M.M. Mikha, K.R. Sistani, P.W. Stahlman, J.G. Benjamin, M.F. Vigil, and R. Erickson. 2011. Multi-location study of soil enzyme activities as affected by types and rates of manure application and tillage practices. Agriculture 1(1):4-21.

Andrews, S.S., D.L. Karlen, and C.A. Cambardella. 2004. The soil management assessment framework. Soil Science Society of America Journal 68(6):1945-1962.

Aoyama, M., D. Angers, and A. N'dayegamiye. 1999. Particulate and mineral-associated organic matter in water-stable aggregates as affected by mineral fertilizer and manure applications. Canadian Journal of Soil Science 79(2):295-302.

Asada, K., K. Toyota, T. Nishimura, J.-I. Ikeda, and K. Hori. 2010. Accumulation and mobility of zinc in soil amended with different levels of pig-manure compost. Journal of Environmental Science and Health Part B 45(4):285-292.

Barber, S. 1979. Soil phosphorus after 25 years of cropping with five rates of phosphorus application. Communications in Soil Science and Plant Analysis 10(11):1459-1468.

Berenguer, P., S. Cela, F. Santiveri, J. Boixadera, and J. Lloveras. 2008. Copper and zinc soil accumulation and plant concentration in irrigated maize fertilized with liquid swine manure. Agronomy Journal 100(4):1056-1061.

Blesh, J., and L. Drinkwater. 2013. The impact of nitrogen source and crop rotation on nitrogen mass balances in the Mississippi River Basin. Ecological Applications 23(5):1017-1035.

Brun, L., J. Maillet, P. Hinsinger, and M. Pepin. 2001. Evaluation of copper availability to plants in coppercontaminated vineyard soils. Environmental Pollution 111(2):293-302.

Bruns, H.A., and M.W. Ebelhar. 2006. Nutrient uptake of maize affected by nitrogen and potassium fertility in a humid subtropical environment. Communications in Soil Science and Plant Analysis 37(1-2):275-293.

Bünemann, E.K., G. Bongiorno, Z. Bai, R.E. Creamer, G. De Deyn, R. de Goede, L. Fleskens, V. Geissen, T.W. Kuyper, and P. Mäder. 2018. Soil quality-A critical review. Soil Biology and Biochemistry 120:105-125.

Butcher, K., A.F. Wick, T. DeSutter, A. Chatterjee, and J. Harmon. 2018. Corn and soybean yield response to salinity influenced by soil texture. Agronomy Journal 110(4):1243-1253.

Cakmak, I. 2002. Plant nutrition research: Priorities to meet human needs for food in sustainable ways. Plant and Soil 247:3-24

Calderon, FJ., M.F. Vigil, and J. Benjamin. 2018. Compost input effect on dryland wheat and forage yields and soil quality. Pedosphere 28(3):451-462.

Chaney, K., and R. Swift. 1984. The influence of organic matter on aggregate stability in some British soils. Journal of Soil Science 35(2):223-230.

Ciampitti, I.A., J.J. Camberato, S.T. Murrell, and T.J. Vyn. 2013. Maize nutrient accumulation and partitioning in response to plant density and nitrogen rate: I. Macronutrients. Agronomy Journal 105(3):783-795.

Ciampitti, I.A., and T.J. Vyn. 2013. Maize nutrient accumulation and partitioning in response to plant density and nitrogen rate: II. Calcium, magnesium, and micronutrients. Agronomy Journal 105(6):1645-1657.

Davis, J.G., D.G. Westfall, J. Mortvedt, and R. Croissant. 2009. Fertilizing Corn. Fort Collins, CO: Colorado State University Extension.

Delgado, J., M. Shaffer, C. Hu, R. Lavado, J. Cueto-Wong, P. Joosse, D. Sotomayor, W. Colon, R. Follett, S. DelGrosso, X. Li, H. Rimski-Korsakov. 2008. An index approach to assess nitrogen losses to the environment. Ecological Engineering 32(2):108-120.

Doran, J.W., and T.B. Parkin. 1994. Defining and assessing soil quality. In Defining Soil Quality for a Sustainable Environment, eds.J.W.Doran,D.C.Coleman,D.F.Bezdicek, and B.A. Stewart, 3-21. Madison, WI: Soil Science Society of America, American Society of Agronomy.

Drinkwater, L.E., C.A. Cambardella, J.D. Reeder, and C.W. Rice. 1996. Potentially mineralizable nitrogen as an indicator of biologically active soil nitrogen. In Methods for Assessing Soil Quality, eds. J.W. Doran and A.J. Jones, 217229. Soil Science Society of America Special Publication 49. Madison, WI: Soil Science Society of America.

Eghball, B. 2002. Soil properties as influenced by phosphorusand nitrogen-based manure and compost applications. Agronomy Journal 94(1):128-135. 
Eghball, B., G. Binford, and D.D. Baltensperger. 1996. Phosphorus movement and adsorption in a soil receiving long-term manure and fertilizer application. Journal of Environmental Quality 25(6):1339-1343.

Eghball, B., D. Ginting, and J.E. Gilley. 2004. Residual effects of manure and compost applications on corn production and soil properties. Agronomy Journal 96(2):442-447.

Eghball, B., and J.F. Power. 1999a. Composted and noncomposted manure application to conventional and no-tillage systems: Corn yield and nitrogen uptake. Agronomy Journal 91(5):819-825.

Eghball, B., and J.F. Power. 1999b. Phosphorus- and nitrogenbased manure and compost applications corn production and soil phosphorus. Soil Science Society of America Journal 63(4):895-901.

Eghball, B., D. Sander, and J. Skopp. 1990. Diffusion, adsorption, and predicted longevity of banded phosphorus fertilizer in three soils. Soil Science Society of America Journal 54(4):1161-1165.

Eghball, B., J.F. Shanahan, G.E. Varvel, and J.E. Gilley. 2003. Reduction of high soil test phosphorus by corn and soybean varieties. Agronomy Journal 95(5):1233-1239.

Eghball, B., B.J. Wienhold, J.E. Gilley, and R.A. Eigenberg. 2002. Mineralization of manure nutrients. Journal of Soil and Water Conservation 57(6):470-473.

Eghball, B., B.J. Wienhold, B.L. Woodbury, and R.A. Eigenberg. 2005. Plant availability of phosphorus in swine slurry and cattle feedlot manure. Agronomy Journal 97(2):542-548.

Eivazi, F., and M. Tabatabai. 1988. Glucosidases and galactosidases in soils. Soil Biology and Biochemistry 20(5):601-606

Fageria, N., V. Baligar, and R. Clark. 2002. Micronutrients in crop production. In Advances in Agronomy, ed. D.L. Sparks, 185-268. San Diego, CA: Academic Press.

Feil, B. 2001. Phytic acid. Journal of New Seeds 3(3):1-35.

Feil, B., S.B. Moser, S. Jampatong, and P. Stamp. 2005. Mineral composition of the grains of tropical maize varieties as affected by pre-anthesis drought and rate of nitrogen fertilization. Crop Science 45(2):516-523.

Fuglie, K., P. Heisey, J. King, C.E. Pray, and D. Schimmelpfennig. 2012. The contribution of private industry to agricultural innovation. Science 338(6110):1031-1032.

Garcia-Gil, J., C. Plaza, P. Soler-Rovira, and A. Polo. 2000. Long-term effects of municipal solid waste compost application on soil enzyme activities and microbial biomass. Soil Biology and Biochemistry 32(13):1907-1913.

Gillabel, J., K. Denef, J. Brenner, R. Merckx, and K. Paustian. 2007. Carbon sequestration and soil aggregation in center-pivot irrigated and dryland cultivated farming systems. Soil Science Society of America Journal 71(3):1020-1028.

Graham, R.D., R.M.Welch, and H.E. Bouis. 2001.Addressing micronutrient malnutrition through enhancing the nutritional quality of staple foods: Principles, perspectives and knowledge gaps. Advances in Agronomy 70:77-142. Grusak, M.A., and D. DellaPenna. 1999. Improving the nutrient composition of plants to enhance human nutrition and health. Annual Review of Plant Biology 50(1):133-161.

Grusak, M.A., J. Pearson, and E. Marentes. 1999. The physiology of micronutrient homeostasis in field crops. Field Crops Research 60(1):41-56.

Gupta, U.C., W. Kening, and S. Liang. 2008. Micronutrient in soils, crops, and livestock. Earth Science Frontiers 15(5):110-125

Halvorson, A.D., and J.M. Johnson. 2009. Corn cob characteristics in irrigated central Great Plains studies. Agronomy Journal 101(2):390-399.

Halvorson, A.D., C.E. Stewart, and S.J. Del Grosso. 2016. Manure and inorganic nitrogen affect irrigated corn yields and soil properties. Agronomy Journal 108(2):519-531.

Hansen, N.C., T. Daniel, A. Sharpley, and J. Lemunyon. 2002. The fate and transport of phosphorus in agricultural systems. Journal of Soil and Water Conservation 57(6):408-417.

Havlin, J.L., J.D. Beaton, S.L. Tisdale, and W.L. Nelson. 2005. Soil Fertility and Fertilizers: An Introduction to Nutrient Management. Upper Saddle River, NJ Pearson Prentice Hall.

Hay, R.K., and J.R. Porter. 2006. The Physiology of Crop Yield. Ames, IA: Blackwell Publishing.

Hodgson, J., W. Lindsay, and J. Trierweiler. 1966. Micronutrient cation complexing in soil solution: II. Complexing of zinc and copper in displaced solution from calcareous soils. Soil Science Society of America Journal 30(6):723-726.

Huang, C.Y.L., and E. Schulte. 1985. Digestion of plant tissue for analysis by ICP emission spectroscopy Communications in Soil Science and Plant Analysis 16(9):943-958

Jalali, M., and G. Khanboluki. 2007. Leaching of zinc, cadmium, and lead in a sandy soil due to application of poultry litter. Soil \& Sediment Contamination 16(1):47-60.

Jarausch-Wehrheim, B., B. Mocquot, and M. Mench. 1996 Uptake and partitioning of sludge-borne copper in field-grown maize (Zea mays L.). European Journal of Agronomy 5(3-4):259-271.

Jokela, W.E. 1992. Nitrogen fertilizer and dairy manure effects on corn yield and soil nitrate. Soil Science Society of America Journal 56(1):148-154.

Kallenbach, C., and A.S. Grandy. 2011. Controls over soil microbial biomass responses to carbon amendments in agricultural systems: A meta-analysis. Agriculture, Ecosystems and Environment 144(1):241-252.

Kemper, W.D., and R.C. Rosenau. 1986. Aggregate stability and size distribution. In Methods of Soil Analysis: Part 1-Physical and Mineralogical Methods, ed. A. Klute,
425-442. Madison, WI: Soil Science Society of America, American Society of Agronomy.

Khattak, R.A., and A. Page. 2017. Mechanism of manganese adsorption on soil constituents. In Biogeochemistry of Trace Metals, ed. D.C. Adriano, 395-412. Boca Raton, FL: CRC Press.

Kincaid, R., J. Hillers, and J. Cronrath. 1981. Calcium and phosphorus supplementation of rations for lactating cows. Journal of Dairy Science 64(5):754-758.

Kleinman, P.J., A.R. Buda, A.N. Sharpley, and R. Khosla. 2018. Elements of precision manure management. In Precision Conservation: Geospatial Techniques for Agricultural and Natural Resources Conservation, eds. J.A. Delgado, G.F. Sassenrath, and T. Muller. Madison, WI: American Society of Agronomy, Crop Science Society of America, Soil Science Society of America.

Kochian, L.V. 1991. Mechanisms of micronutrient uptake and translocation in plants. In Micronutrients in Agriculture, eds. J. Mortvedt, F. Cox, L. Shuman, and R. Welch, 229296. Madison, WI: Soil Science Society of America.

Kornegay, E., J. Hedges, D. Martens, and C. Kramer. 1976 Effect on soil and plant mineral levels following application of manures of different copper contents. Plant and Soil 45(1):151-162.

Leikam, D.F., and R.E. Lamond. 2003. Estimating Manure Nutrient Availability. Kansas State University Agricultural Experiment Station and Cooperative Extension Service Bulletin MF-2526. Manhattan, KS Kansas State University.

Lentz, R., and J. Ippolito. 2012. Biochar and manure affect calcareous soil and corn silage nutrient concentrations and uptake. Journal of Environmental Quality 41(4):1033-1043.

Li, B., D. Zhou, L. Cang, H. Zhang, X. Fan, and S. Qin. 2007. Soil micronutrient availability to crops as affected by long-term inorganic and organic fertilizer applications. Soil and Tillage Research 96(1):166-173.

Lindsay, W., and W. Norvell. 1978. Development of a DTPA soil test for zinc, iron, manganese, and copper. Soil Science Society of America Journal 42(3):421-428.

Lindsay, W., and A. Schwab. 1982. The chemistry of iron in soils and its availability to plants. Journal of Plant Nutrition 5(4-7):821-840.

Losak, T., J. Hlusek, J. Martinec, J. Jandak, M. Vitezova, R. Filipcik, J. Manasek, K. Prokes, J. Peterka, L. Varga, L. Ducsay, F. Orosz, and A. Martensson. 2011. Nitrogen fertilization does not affect micronutrient uptake in grain maize (Zea mays L.). Acta Agriculturae Scandinavica, Section B-Soil \& Plant Science 61(6):543-550.

Lott, J.N., I. Ockenden, V. Raboy, and G.D. Batten. 2000. Phytic acid and phosphorus in crop seeds and fruits: A global estimate. Seed Science Research 10(1):11-33.

Ma, B., L.M. Dwyer, and E.G. Gregorich. 1999. Soil nitrogen amendment effects on seasonal nitrogen mineralization and nitrogen cycling in maize production. Agronomy Journal 91(6):1003-1009. 
Maas, E.V., and G.J. Hoffman. 1977. Crop salt tolerancecurrent assessment. Journal of the Irrigation and Drainage Division 103(2):115-134.

Maillard, É., and D.A. Angers. 2014. Animal manure application and soil organic carbon stocks: A metaanalysis. Global Change Biology 20(2):666-679.

Mallarino, A.P. 1996. Evaluation of optimum and aboveoptimum phosphorus supplies for corn by analysis of plant parts. Agronomy Journal 88(3):376-380.

Mallarino,A.P., R.R. Oltmans, J.R. Prater, C.X.Villavicencio, and L.B.Thompson. 2011. Nutrient uptake by corn and soybean, removal, and recycling with crop residue. In Proceedings of the Integrated Crop Management Conference. https://lib. dr.iastate.edu/icm/2011/proceedings/19.

Mandal, L., and R. Mitra. 1982. Transformation of iron and manganese in rice soils under different moisture regimes and organic matter applications. Plant and Soil 69(1):45-56.

Mantovi, P., G. Bonazzi, E. Maestri, and N. Marmiroli. 2003. Accumulation of copper and zinc from liquid manure in agricultural soils and crop plants. Plant and Soil 250(2):249-257.

Marschner, H. 1995. Mineral Nutrition of Higher Plants. San Diego, CA:Academic Press.

McDowell, L.R. 1996. Feeding minerals to cattle on pasture. Animal Feed Science and Technology 60(3-4):247-271.

McIntosh, J., and K. Varney. 1972. Accumulative effects of manure and $\mathrm{N}$ on continuous corn and clay soil. I. Growth, yield, and nutrient uptake of corn. Agronomy Journal 64(3):374-379.

McLaren, R., and D. Crawford. 1973. Studies on soil copper I. The fractionation of copper in soils. European Journal of Soil Science 24(2):172-181.

Mengel, K., and E. Kirkby. 1982. Principles of Plant Nutrition. Berne, Germany: International Potash Insitute.

Mikha, M.M., G.W. Hergert, J.G. Benjamin, J.D. Jabro, and R.A. Nielsen. 2015. Long-term manure impacts on soil aggregates and aggregate-associated carbon and nitrogen. Soil Science Society of America Journal 79(2):626-636.

Mikha, M.M., and C.W. Rice. 2004. Tillage and manure effects on soil and aggregate-associated carbon and nitrogen. Soil Science Society of America Journal 68(3):809-816.

Miller, D.D., and R.M. Welch. 2013. Food system strategies for preventing micronutrient malnutrition. Food Policy 42:115-128.

Miner, G.L., J.A. Delgado, J.A. Ippolito, K.A. Barbarick, C.E. Stewart, D.K. Manter, S.J. Del Grosso, A.D. Halvorson, B.A. Floyd, and R.E. D'Adamo. 2018. Influence of long-term nitrogen fertilization on crop and soil micronutrients in a no-till maize cropping system. Field Crops Research 228:170-182.

Moebius-Clune, B.N., D.J. Moebius-Clune, B.K. Gugino, O.J. Idowu, R.R. Schindelbeck, A.J. Ristow, H.M. van Es, J.E.Thies, H.A. Shayler, M.B. McBride, K.S.M. Kurtz, D.W. Wolfe, and G.S. Abawi. 2016. Comprehensive
Assessment of Soil Health: The Cornell Framework Manual, 3.2 edition. Geneva, NY: Cornell University.

Nuss, E.T., and S.A. Tanumihardjo. 2010. Maize: A paramount staple crop in the context of global nutrition. Comprehensive Reviews in Food Science and Food Safety 9(4):417-436.

Olsen, S.R., C.V. Cole, F.S. Watanabe, and L.A. Dean. 1954. Estimation of Available Phosphorus in Soils by extraction With Sodium Bicarbonate. Circular 939. Washington, DC: USDA.

Pepper, I.L. 2013. The soil health-human health nexus. Critical Reviews in Environmental Science and Technology 43(24):2617-2652.

Raboy,V. 2001. Seeds for a better future: 'Low phytate'grains help to overcome malnutrition and reduce pollution. Trends in Plant Science 6(10):458-462.

Rengel, Z., G. Batten, and D. Crowley. 1999. Agronomic approaches for improving the micronutrient density in edible portions of field crops. Field Crops Research 60(1):27-40.

Ribaudo, M., J. Delgado, L. Hansen, M. Livingston, R. Mosheim, and J. Williamson. 2011. Nitrogen in Agricultural Systems: Implications for Conservation Policy. Economic Research Report 127. Washington, DC: USDA Economic Research Service.

Riedell, W.E., J.L. Pikul, A.A. Jaradat, and T.E. Schumacher. 2009. Crop rotation and nitrogen input effects on soil fertility, maize mineral nutrition, yield, and seed composition. Agronomy Journal 101(4):870-879.

Roper, W.R., D.L. Osmond, J.L. Heitman, M.G. Wagger, and S.C. Reberg-Horton. 2017. Soil health indicators do not differentiate among agronomic management systems in North Carolina soils. Soil Science Society of America Journal 81(4):828-843.

SAS Institute. 2013. SAS Software Version 9.4. Cary, NC: SAS Institute, Inc.

Schlegel, A.J., Y. Assefa, H.D. Bond, L.A. Haag, and L.R. Stone. 2017. Changes in soil nutrients after 10 years of cattle manure and swine effluent application. Soil and Tillage Research 172:48-58.

Schröder, J. 2005. Revisiting the agronomic benefits of manure: A correct assessment and exploitation of its fertilizer value spares the environment. Bioresource Technology 96(2):253-261.

Sharpley, A.N., J.L. Weld, D.B. Beegle, P.J. Kleinman, W. Gburek, P. Moore, and G. Mullins. 2003. Development of phosphorus indices for nutrient management planning strategies in the United States. Journal of Soil and Water Conservation 58(3):137-152.

Sherrod, L., G. Dunn, G. Peterson, and R. Kolberg. 2002. Inorganic carbon analysis by modified pressurecalcimeter method. Soil Science Society of America Journal 66(1):299-305.

Six, J., E. Elliott, and K. Paustian. 2000. Soil macroaggregate turnover and microaggregate formation: A mechanism for $\mathrm{C}$ sequestration under no-tillage agriculture. Soil Biology and Biochemistry 32(14):2099-2103.
Stott, D., S. Andrews, M. Liebig, B.J. Wienhold, and D. Karlen. 2010. Evaluation of $\beta$-glucosidase activity as a soil quality indicator for the soil management assessment framework. Soil Science Society of America Journal 74(1):107-119.

USDA NRCS (USDA Natural Resources Conservation Service). 2019. Soil Health. https://www.nrcs.usda.gov/ wps/portal/nrcs/main/soils/health/.

Van der Bom, F., J. Magid, and L.S. Jensen. 2019. Long-term fertilisation strategies and form affect nutrient budgets and soil test values, soil carbon retention and crop yield resilience. Plant and Soil 434(1-2):47-64.

Vitosh, M., J. Davis, and B. Knezek. 1973. Long-term effects of manure, fertilizer, and plow depth on chemical properties of soils and nutrient movement in a monoculture corn system. Journal of Environmental Quality 2(2):296-299.

Wall, D.H., U.N. Nielsen, and J. Six. 2015. Soil biodiversity and human health. Nature 528(7580):69.

Walsh, L.M., and J.D. Beaton. 1973. Soil Testing and Plant Analysis. Madison, WI: Soil Science Society of America, Inc.

Warkentin, B.P. 1995. The changing concept of soil quality. Journal of Soil and Water Conservation 50(3):226-228.

Woli, K.P., J.E. Sawyer, M.J. Boyer, L.J. Abendroth, and R.W. Elmore. 2018. Corn era hybrid macronutrient and dry matter accumulation in plant components. Agronomy Journal 110(5):1648-1658. 